
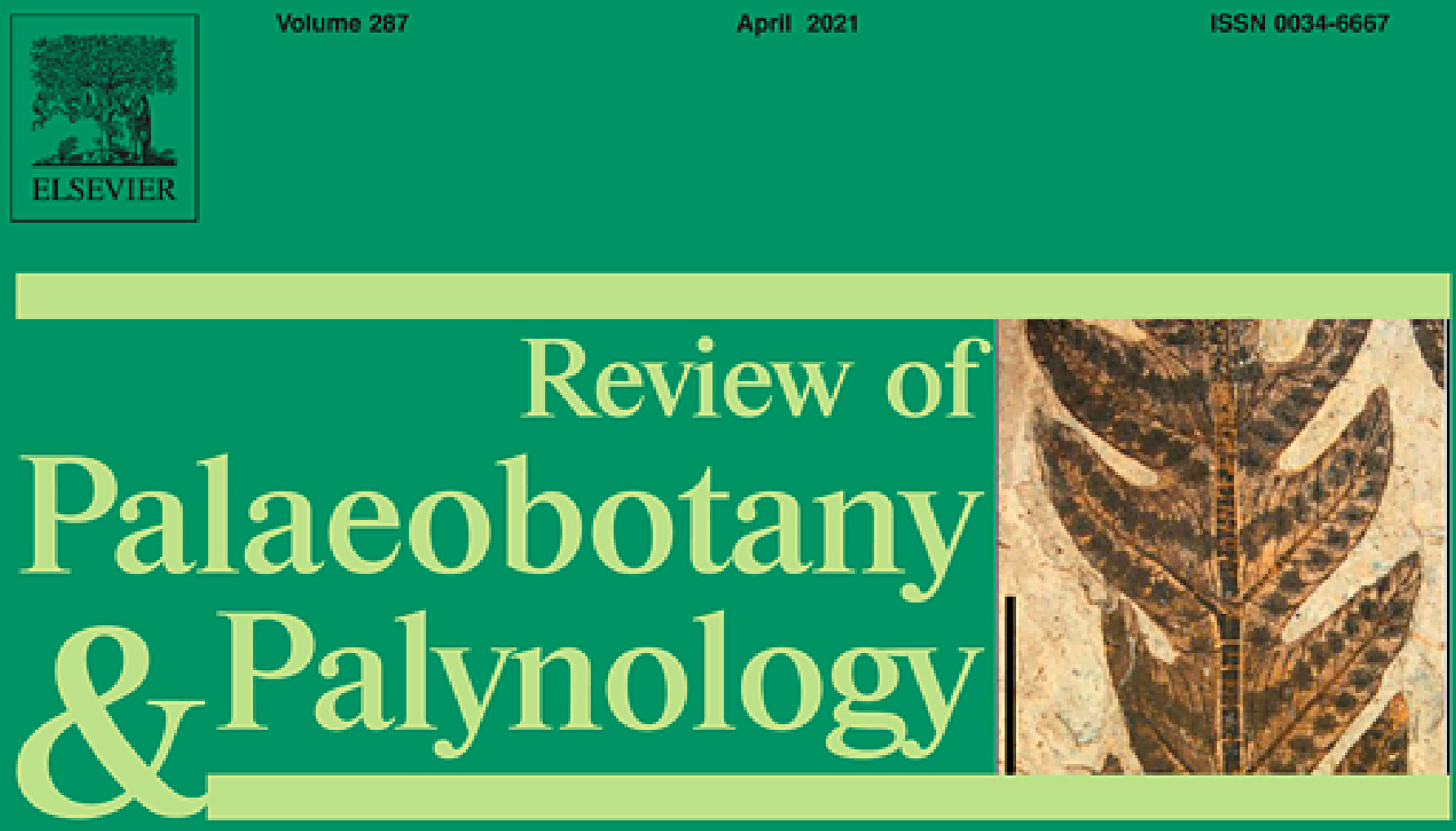

Editors-in-Chief 


\title{
Eupolypod ferns with dryopteroid/thelypteroid traits from Arroyo Chacay (Huitrera Formation, Eocene), Río Negro Province, Argentina
}

\author{
Matías A. Machado a,f,* Ezequiel I. Vera a,b,f, Mauro G. Passalia ${ }^{\text {c,d,f, }}$, Mónica M. Ponce ${ }^{\text {e,f }}$ \\ a Museo Argentino de Ciencias Naturales "Bernardino Rivadavia”, CONICET. Av. Ángel Gallardo 470 (C1405DJR), Buenos Aires, Argentina \\ b Área de Paleontología, Departamento de Geología, Universidad de Buenos Aires, Pabellón 2, Ciudad Universitaria (C1428EGA), Buenos Aires, Argentina \\ ${ }^{c}$ Instituto de Investigaciones en Biodiversidad y Medioambiente (INIBIOMA, CONICET-UNCo), Av. de los Pioneros 2350 (8400), S.C. de Bariloche, Río Negro, Argentina \\ d Sede Alto Valle y Valle Medio, Universidad Nacional de Río Negro, Isidro Lobo 516, Gral. Roca, Río Negro, Argentina \\ e Instituto de Botánica Darwinion (IBODA, CONICET), Labardén 200, Casilla de Correo 22, (B1642HYD), San Isidro, Argentina \\ ${ }^{\mathrm{f}}$ Consejo Nacional de Investigaciones Científicas y Técnicas (CONICET), Buenos Aires, Argentina
}

\section{A R T I C L E I N F O}

\section{Article history:}

Received 4 August 2020

Received in revised form 18 December 2020

Accepted 13 January 2021

Available online 23 January 2021

\section{Keywords:}

Fossil ferns

Patagonia

Tapelrayen

Cyclosorus

Thelypteris

\begin{abstract}
A B S T R A C T
The Huitrera Formation is a sequence of volcanic deposits that outcrops in the northwestern region of Patagonia. Several paleofloras have been recognized in this (or in coeval) units, in classical localities named Pichileufu, Confluencia, Pampa de Jones and Laguna del Hunco. These works, focused mostly on the angiosperm and conifer content of the unit, allowed the recognition of a diverse array of taxa. Nevertheless, ferns remain underrepresented in the literature. In this work, three ferns preserved as impressions/compressions are described for this unit, collected from outcrops at the Arroyo Chacay locality. A new genus and species (Tapelrayen helgae gen. et sp. nov.) is designated to encompass fertile remains comparable with Thelypteridaceae and Dryopteridaceae. Another fossil form of ambiguous affinities is left in open nomenclature (Eupolypod incertae sedis) and a third form is referred to Cyclosorus sp. cf. C. interruptus (Willd.) H.Itô of the Thelypteridaceae. A discussion on the complex taxonomical scenario that is presented for fossil leaves comparable with Thelypteridaceae and Dryopteridaceae is presented, in light of the recent published taxonomic schemes.
\end{abstract}

(c) 2021 Elsevier B.V. All rights reserved.

\section{Introduction}

Leptosporangiate ferns comprise a distinctive group with extensive and rich fossil records that span from the Paleozoic to present day (Taylor et al., 2009). Ferns are conspicuous elements of the late Paleozoic and Mesozoic plant fossil assemblages, but when referring to Cenozoic floras, angiosperms become dominant, and result the main focus of paleobotanical studies to the detriment of ferns. Collinson (2001) reviewed the Cenozoic record of ferns and stated that they have been less studied. In addition, this author suggests the need of an extensive revision of the previous published taxa. This situation is even more critical when referring to South American fossil floras, which have been less studied than the ones in the Northern Hemisphere. Although there are numerous Cenozoic fossil sites with highly diverse and rich floras, the number of works referring to the megafloral fern content of these assemblages is comparatively low. In particular, northern Argentinian Patagonia holds many Eocene outcrops with plant assemblages

\footnotetext{
* Corresponding author at: Museo Argentino de Ciencias Naturales "Bernardino Rivadavia”, CONICET. Av. Ángel Gallardo 470 (C1405DJR), Buenos Aires, Argentina.

E-mail addresses: agus.machado7@gmail.com (M.A. Machado), evera@macn.gov.ar (E.I. Vera), passaliam@comahue-conicet.gob.ar (M.G. Passalia), mponce@darwin.edu.ar (M.M. Ponce).
}

(e.g. Laguna del Hunco, Confluencia, Arroyo Chacay, Pampa de Jones and Pichileufu). These locations were the aim of many studies, but few of them informed the presence of fossil ferns (Berry, 1938; Melendi et al., 2003; Wilf et al., 2003, 2005, 2010; Carvalho et al., 2013; Bomfleur and Escapa, 2019). Although ferns are comparatively less represented than other plant groups in the mentioned assemblages (Berry, 1938; Wilf et al., 2003, 2005, 2010) they still are a recognizable component of the flora and can potentially shed new data for understanding the diversification of modern lineages. The present study identifies the presence of eupolypod ferns in the Eocene flora of Arroyo Chacay (Huitrera Formation) from Río Negro, Argentina.

\section{Materials and methods}

\subsection{Provenance of the studied samples}

The materials were collected at the Arroyo Chacay location, $45 \mathrm{~km}$ north of San Carlos de Bariloche (40 48 $17^{\prime \prime}$ 'S $71^{\circ} 1^{\prime} 58^{\prime \prime}$ W) Río Negro Province (Fig. 1), in deposits referred to the Huitrera Formation by Escosteguy et al. (2013). The fossils are housed in the collection of the Museo de la Asociación Paleontológica Bariloche, under MAPBAR acronym. 


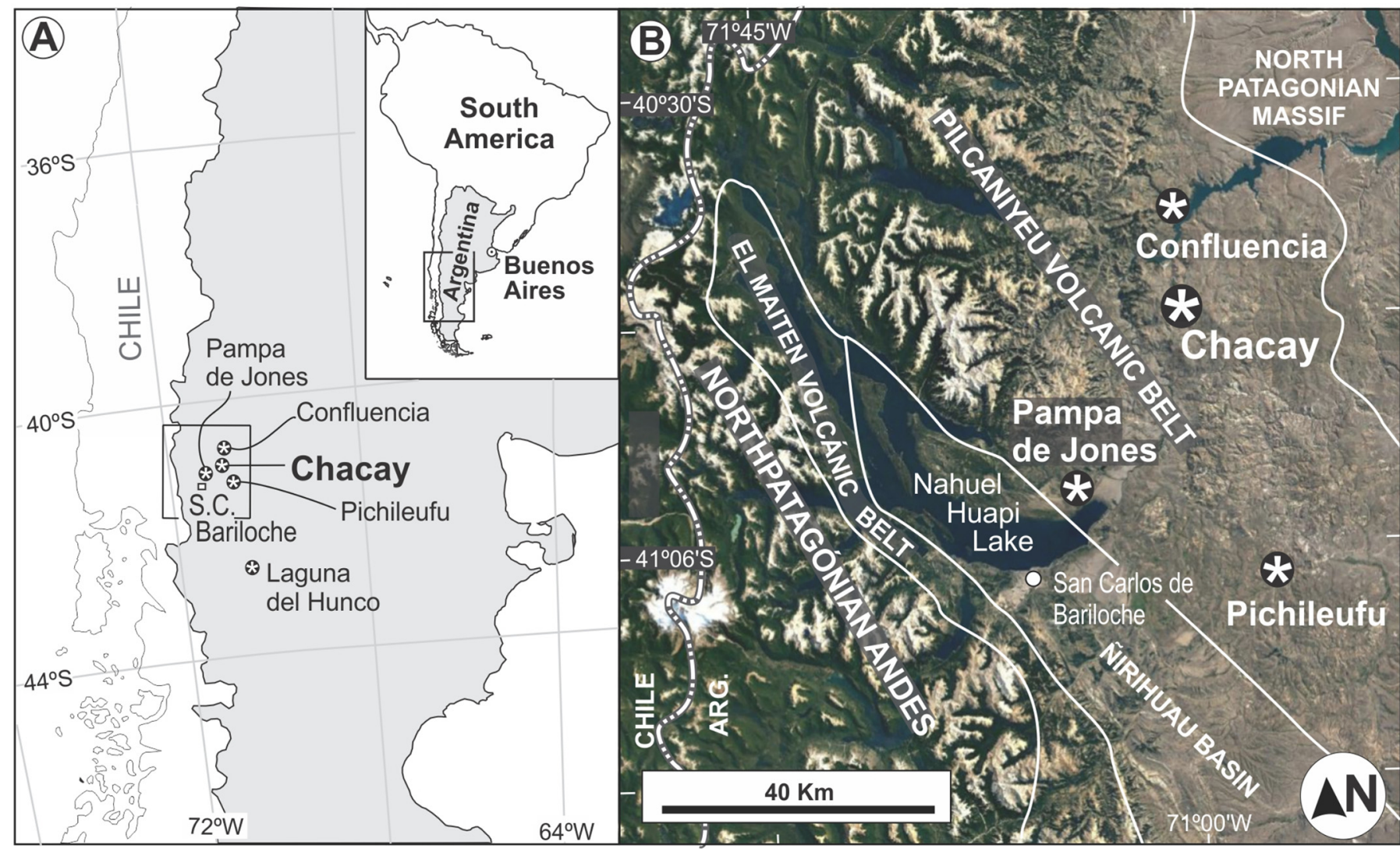

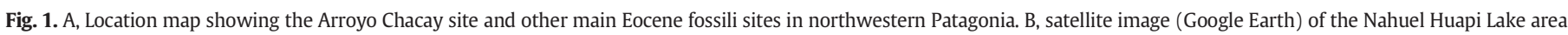
showing fossil sites and the approximate limits of the main morphostructural units of the Andean margin (modified from Bechis et al., 2014).

\subsection{Preparation of samples and observation}

The fossils consist of impressions and compressions of sterile and fertile fern leaves preserved in laminated mudstones. When needed, a pneumatic hammer was used to expose more features of the fossils. The spores were obtained mechanically removing sori with a dissection needle. For its observation with optic microscope, the material was mounted on a slide using Noetinger et al. (2017) methodology. For observation under Scanning Electron Microscopy (SEM), the materials were mounted on an aluminum peg using adhesive film and coated with gold-palladium. The fossils surface was studied with a Nikon SMZ800 microscope. Measuring was carried out using ruler and measuring software included in the Nikon Digital Sight DS-L2 digital camera control unit connected to the microscope. Palynomorphs were observed with an Olympus BX-51 optical microscope, and also with Phillips XL30 Scanning Electron Microscope at Service of the MACNBR (Museo Argentino de Ciencias Naturales Bernardino Rivadavia). Photographs of fossil fern specimens studied by Berry (1938) and herbarium specimens from Instituto de Botánica Darwinion (SI) and from the virtual herbarium pteridoportal (www.pteridoportal.org) were consulted for morphological comparisons.

\subsection{Systematic classification and terminology}

The Pteridophyte Phylogeny Group systematic treatment is followed here (PPG I, 2016), which recognizes four subclasses for Polypodiopsida: Equisetidae, Ophioglossidae, Marattidae and Polypodiidae. Among Polypodiidae, seven orders are recognized: Osmundales, Hymenophyllales, Gleicheniales, Schizaeales, Salviniales, Cyatheales and Polypodiales, the latter including families Thelypteridaceae and Dryopteridaceae among others.
The generic classification for Thelypteridaceae is mostly based on the results obtained in molecular phylogenetic studies made by Almeida et al. (2016), also summarized in the PPG I (2016) work. As Almeida et al. (2016) point out, the inclusion of more taxa of the many recognized in the neotropical region (Tryon and Tryon, 1982) is key to reconstruct the phylogenetic history of the family. In South America the traditional systematic and taxonomical approach has been followed for extant species, and as such this nomenclatural terminology is very common in the literature. A thorough re-study of the diversity of American taxa in light of molecular methods and recent papers is of great necessity. In this context, fossil studies play an important role to reconstruct the origin of local flora. Ponce (1987) revised the Argentinian species of Thelypteridaceae, and discussed several morphological features that allow separating taxa, including venation pattern, leaf morphology, pinnae morphology, and other features. The taxonomical scheme followed by Ponce is commonly used in local (Argentinian) literature to refer to this family (e.g. Ponce, 2016). See Supplementary material 1 for the equivalence between the PPG I systematic scheme and the one followed by Ponce $(1987,2016)$.

Descriptions are based on the standarized format followed by Miller and Hickey (2008) with modifications. The fossils studied here are leaf fragments of which there is no certainty about the degree of lamina dissection or general organization. The usage of the terms segment, pinnule and pinna in the literature is variable. In some published descriptions the ultimate divisions of the lamina are called pinnules, whereas others call them segments. It also occurs that due to homology hypothesis, what could be called pinnule by morphological features, is called pinna if attached to a main rachis. Therefore, we relevantly clarify terminology used in this work (Fig. 2). The term segment is here applied to the ultimate recognizable lamina division. This criterion is widely used in bibliography on extant Thelypteridaceae (Ponce, 1987; Smith, 1990). Also, 
the term pinna here refers to a lamina division with its axis united to the main rachis. The sinus membrane is here used in the sense of Ching (1963) and Holttum et al. (1970) to refer to the laminar extension between adjacent segments to which no veins enter. The typological characterization of pinnae and venation pattern is based on the proposal of Ponce (1987). Other fern descriptive terminologies have been adopted from classical literatures (e.g. Tryon, 1960; Lellinger, 2002).

\section{Geological setting}

The Arroyo Chacay fossiliferous locality is found $45 \mathrm{~km}$ north of San Carlos de Bariloche, Río Negro Province, Argentina (Fig. 1). The geological evolution of the Arroyo Chacay area during the Cenozoic is directly linked to the Andean orogeny which had started at the Early Cretaceous (Escosteguy et al., 2013). During the majority of the Paleogene, a large volcanic belt was developed in north-northwest direction in the northwestern Patagonia. The eastern branch of this belt, known as Pilcaniyeu Volcanic Belt, is lithostratigraphically represented by the Huitrera Formation, which consists of volcanic deposits and continental epiclastic components, that contain the studied fossils (Rapela et al., 1988; Escosteguy et al., 2013; Falco et al., 2019). As mentioned by Cazau et al. (2005), the Pilcaniyeu Volcanic Belt or the Huitrera Formation is correlated with the formerly named Serie Andesítica Extraandina (Groeber, 1929, 1954; Feruglio, 1941; Volkheimer, 1964; Ramos, 1982; Rapela et al., 1984), or the Ventana Formation (Rabassa, 1974, 1978; González Bonorino and González Bonorino, 1978) and is equivalent to the Huenuluán Formation (Coira, 1979, in Ardolino et al., 1999), Ignimbrita Barda Colorada (Mazzoni and Rapela, 1991) and the Laguna del Hunco Formation (Petersen 1946, in Ardolino et al., 1999). In the study area the Huitrera Formation deposits are underlain by crystalline bedrock and Permian granite due to erosive discordance, and overlain partially by the Neogene deposits of the Collón Cura and Caleufú Formations by means of an angular discordance (Escosteguy et al., 2013).

\subsection{Age}

Radiometric datings of the fossiliferous sediments outcropped near Arroyo Chacay have yielded $47.46 \pm 0.05$ My (Wilf et al., 2005,
Pichileufu, 40Ar/39Ar values), $54.24 \pm 0.45 \mathrm{My}$ (Wilf et al., 2010, Pampa de Jones, 40Ar/39Ar) and $52.3 \pm 3$ My (Rapela et al., 1983, 1984 , Confluencia, K/Ar) which places these deposits in the lower Eocene. Additionally,51.91 $\pm 0.22 \mathrm{My}(40 \mathrm{Ar} / 39 \mathrm{Ar})$ was obtained for Laguna del Hunco location (Chubut) placed in the southernmost limits of the Pilcaniyeu Volcanic Belt (Wilf et al., 2005). All the obtained datings place these deposits in the Eocene, an age here accepted at the moment for the Arroyo Chacay paleoflora.

\section{Systematic paleobotany}

Order: POLYPODIALES Link (1833)

Clade: Eupolypods sensu PPG I (2016)

Family: incertae sedis

Fossil genus: Tapelrayen gen. nov.

Type species: Tapelrayen helgae sp. nov. (this work)

Diagnosis: Impression/Compression of fossil fern leaf. Leaf pinnate. Pinnae pinnatifid, inserted at approximately $45^{\circ}$ by a short petiolule. Dissection catadromous. Segments falcate with acute apex and entire margins, basalmost pair smaller and subtriangular. Sinuses rounded developing a crescent-shaped membrane. Segments vascularized by a stout midvein that reaches segment apex and unbranched lateral veins terminating at margin. Basalmost pair of lateral veins from adjacent segments connivent toward the sinus ending below it without reaching the margin. Basalmost basiscopic vein arising directly from the costa instead of the midvein. Sori abaxial, located on lateral veins approximately equidistant between the middle vein and the margin, circular; each sorus consisting of ca. 30 lacrimiform sporangia. Indusium small, peltate, and elliptical. Spores monolete, oval to subcircular. Exine thin and smooth.

Etymology: Derived from the mapundungun words tapël (leaf) and rayen (fertile).

Species: Tapelrayen helgae sp. nov.

Fig. 3a, Plates I and II.

Dryopteridaceae sp. Machado, 2019. figs. 13-16.

Etymology: Dedicated to Helga Smekal, former president of the Asociación Paleontológica Bariloche, who collected many of the specimens that form part of the Paleontological Collection of the Museo de

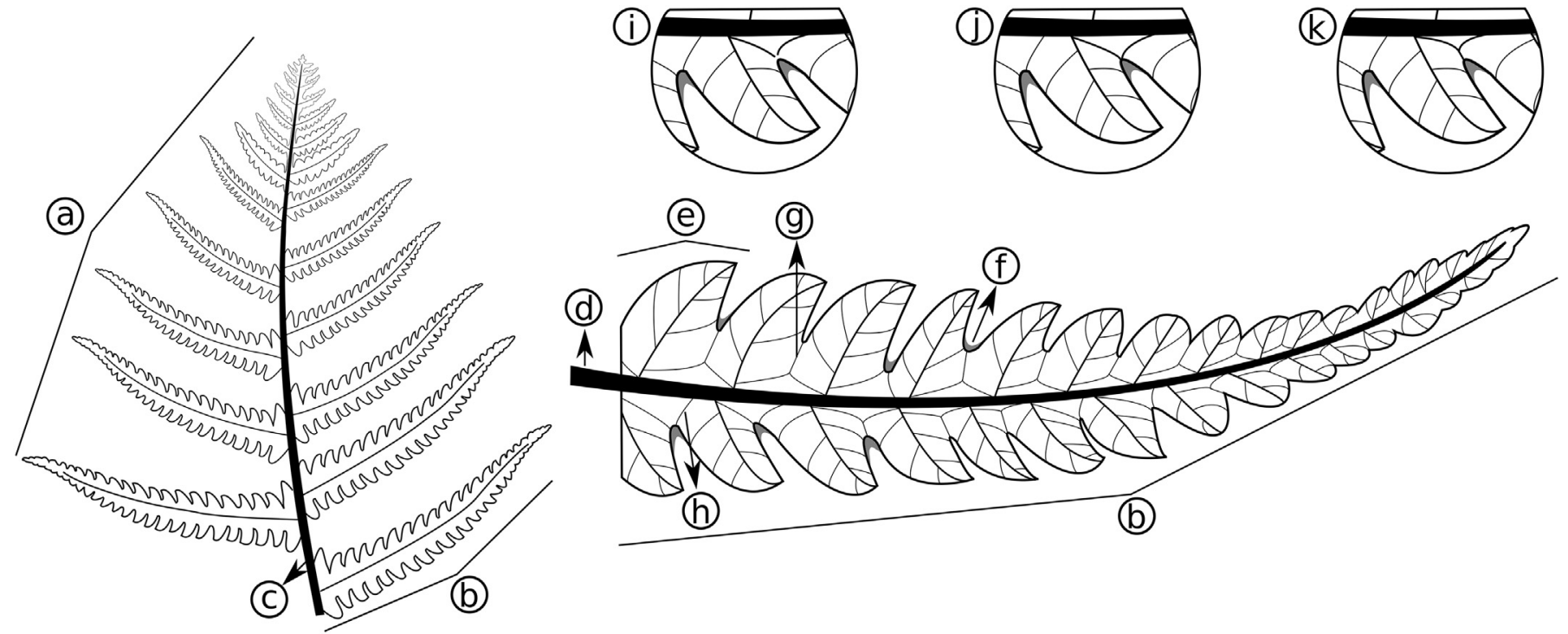

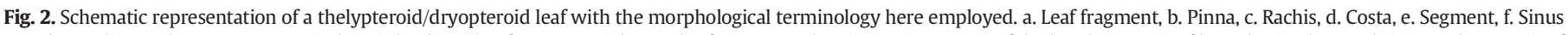

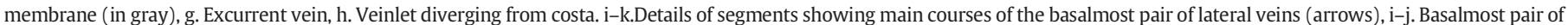

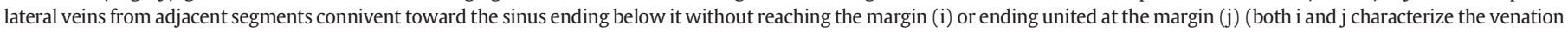

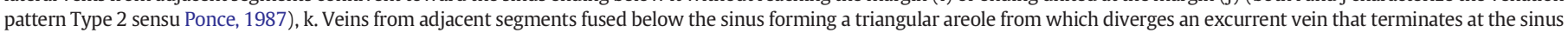
(venation pattern Type 3 sensu Ponce, 1987). 

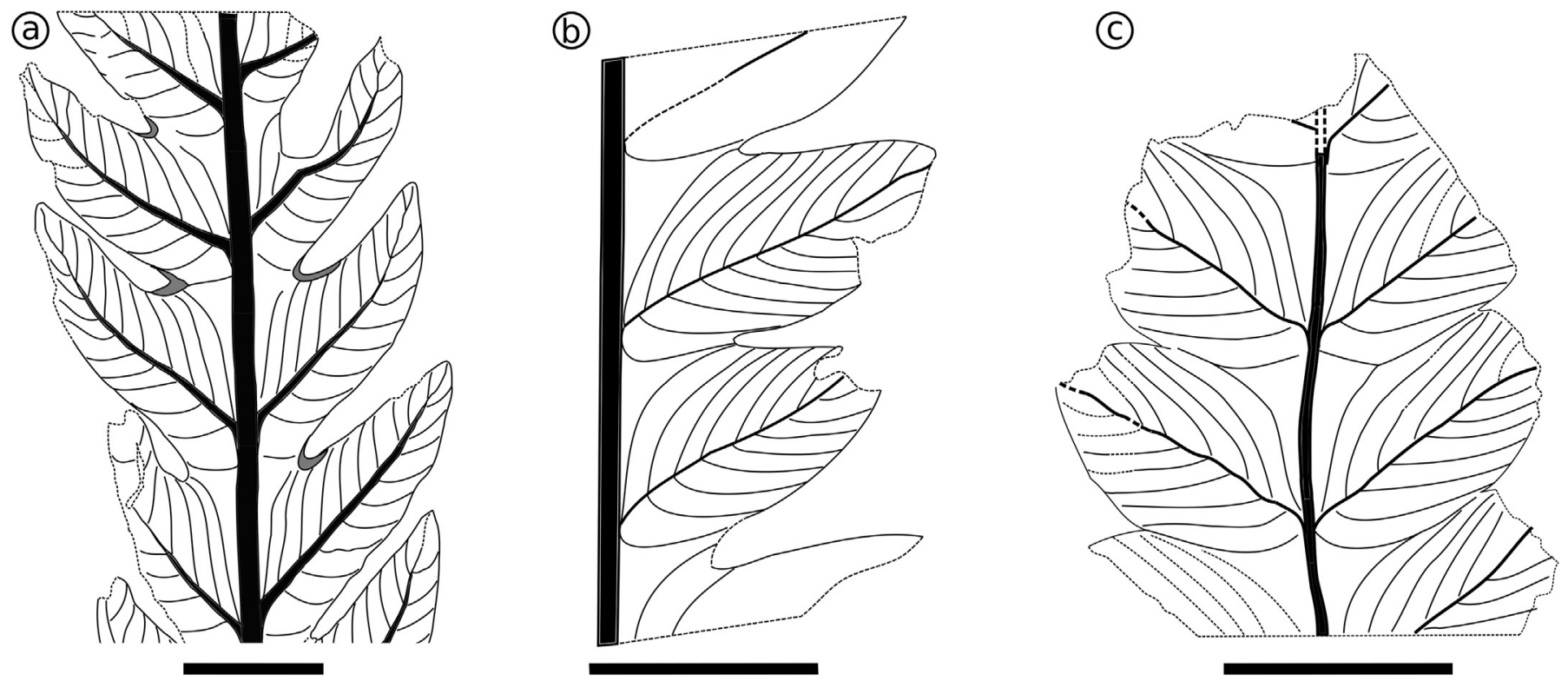

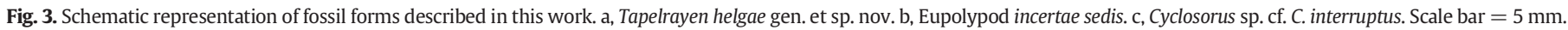

la Asociación Paleontológica Bariloche, including the type specimen of this species.

Locality: Arroyo Chacay.

Holotype: MAPBAR 2999-3.

Additional material: MAPBAR 6700-3, 6701-3.

Stratigraphic Horizon: Huitrera Formation.

Age: Eocene.

Diagnosis: Same as for the genus, by monotipy.

Description: Complete leaves unknown. Sterile leaf unknown. Fertile leaf pinnate, at least $12,5 \mathrm{~cm}$ long, $16,4 \mathrm{~cm}$ wide (Plate I, 1 ); rachis stout, straight, at least $1,8 \mathrm{~mm}$ wide (Plate I, 5); costa stout, straight proximally but slightly curved toward its apex, width up to $1,1 \mathrm{~mm}$, adaxially grooved (Plate I, 1-5), costa groove $0,2-0,4 \mathrm{~mm}$ wide, tapering gradually toward pinna apex. Pinnae pinnatifid, length up to $8,2 \mathrm{~cm}$, width 1-1,4 cm, shape ovate (Plate I, 1-3), attached to the rachis at $45^{\circ}$ angle that decreases distally, with a short petiolule $2 \mathrm{~mm}$ long, dissection catadromous (Plate I, 5). Segments 6,4-10,9 mm long, 5,1-6,8 $\mathrm{mm}$ wide, size decreasing toward pinna apex, $1 / \mathrm{w}$ ratio 1,3-1,6:1, shape typically falcate (Plate I, $1-5$ ), basalmost pair smaller and subtriangular (Type 2 pinna sensu Ponce, 1987; Plate I, 5), attachment alternate to opposite forming a $45^{\circ}$ angle decreasing distally, margins entire (Plate I, 1-5). Adjacent segments fused at base up to $1 / 5-1 / 4$ of their total length (Plate I, 5), fusion between segments increasing toward pinna apex (Plate I, 2-3). Segment apex pointed, markedly acute but rounded in the basalmost pair (Plate I, 4-5), sinuses rounded developing a crescent-shaped sinus membrane up to 0,4-0,6 mm wide (Plate I, 4, 6). Segments vascularized by a stout midvein and 7-11 pairs of lateral unbranched veins that reach the segment margin without anastomosis (Plate I, 4). Midvein 0,2-0,3 $\mathrm{mm}$ wide at base, tapering gradually their gauge toward the segment apex until $0,1 \mathrm{~mm}$ wide. Midvein straight, slightly flexuous, recurved acroscopically until reaching the segment apex. Basiscopic side of the midvein decurrent, diverging gradually from the costa at ca. $45^{\circ}$ angle that decreases toward the distal portion of the pinnae reaching near $30^{\circ}$ (Plate I, 4,6). Lateral veins ca. $0,1 \mathrm{~mm}$ wide, arising from midvein at $30-70^{\circ}$, alternate to opposite, with catadromous dissection. Basalmost pair of veins from adjacent segments connivent toward the sinus ending below it without reaching the margin(Type 2 venation pattern sensu Ponce, 1987; Plate I, 4,6). Basalmost basiscopic lateral vein arising directly from the costa at ca. $90^{\circ}$ instead of the midvein (Plate I, 6). Sori abaxial, borne on the lateral veins of segments, approximately equidistant between the middle vein and the margin (Plate I, 4); number of sori 16-20 per segment, one sorus per vein (Plate I, 4); each sorus circular in outline, indusiate, $0,8-1,2 \mathrm{~mm}$ in diameter, bearing $24-30$ sporangia (Plate II, 1). Indusium reduced, peltate, elliptical in outline, 0,4-0,6 $\mathrm{mm}$ long and 0,2-0,3 mm wide (Plate II, $1,3-4$ ). Sporangium lacrimiform, stalked, ca. 0,2 $\mathrm{mm}$ long and $0,15 \mathrm{~mm}$ wide, with vertical annulus (Plate II, 2). Spores monolete, subcircular to oval in equatorial view (Plate II, 5-12), 28-33 $\mu \mathrm{m}$ long and 21-25 $\mu \mathrm{m}$ wide; laesura straight, simple, reaching $3 / 4$ of the total length (Plate II, 7-8, 10-12); exine thin, $0.7-0.8 \mu \mathrm{m}$ thick, smooth; perispore residues frequently observed on the exine surface (Plate II, 5, 7-8).

Comparisons with fossil taxa:

Diverse fossil forms comparable with Tapelrayen helgae have been described worldwide from Cenozoic sediments. Tapelrayen helgae can be separated from Goniopteris patagoniana Berry (1938), from the Huitrera Formation at the Pichileufu locality, by having a higher number of lateral veins and sori per segment, and by its falcate morphology. In fact, the falcate segments of Tapelrayen helgae is a character state absent in other fossil taxa published elsewhere assigned to the Thelypteridaceae, such as Cyclosorus stiriacus (Unger)Ching et Takht. (= Abacopteris stiriaca (Unger) Ching (Barthel, 1976) = Pronephrium stiriacum (Unger) Knobloch and Kvaček, 1976) a species widely recognized in Oligocene and Miocene deposits of Europe (Pirnea and Popa, 2018), and Cyclosorus scutum Naugolnykh, Wang, Han et Jin from the Eocene of China (Naugolnykh et al., 2016). Speirseopteris orbiculata Stockey, Lantz et Rothwell described from the Paleocene of Canada, at difference of $T$. helgae, has proximal veinlets that meet the margin above the sinus, and fertile segments have rounded tips (Stockey et al., 2006). Thelypteridaceophyllum tertiarum Joshi et Mehrotra from the Miocene of India, has more elongate (not falcate) segments and smaller size (Joshi and Mehrotra, 2003). Specimens referred to Christella from the Cenozoic Liuqu and Sanhaogou formations (China) have nonfalcate segments, and also can be separated by having several lateral veins that connect between segments (Xu et al., 2019). Cyclosorus s.l. reported by Berry (2019) from the K-Pg boundary of USA have segments where the first pair of lateral veins join below the sinus and develop a short excurrent vein. None of these fossils share all character states seen in Tapelrayen helgae.

Comparison with extant species and affinities:

The features of the pinnae and venation recognized in Tapelrayen can be included into one of the typological groups proposed by Ponce 


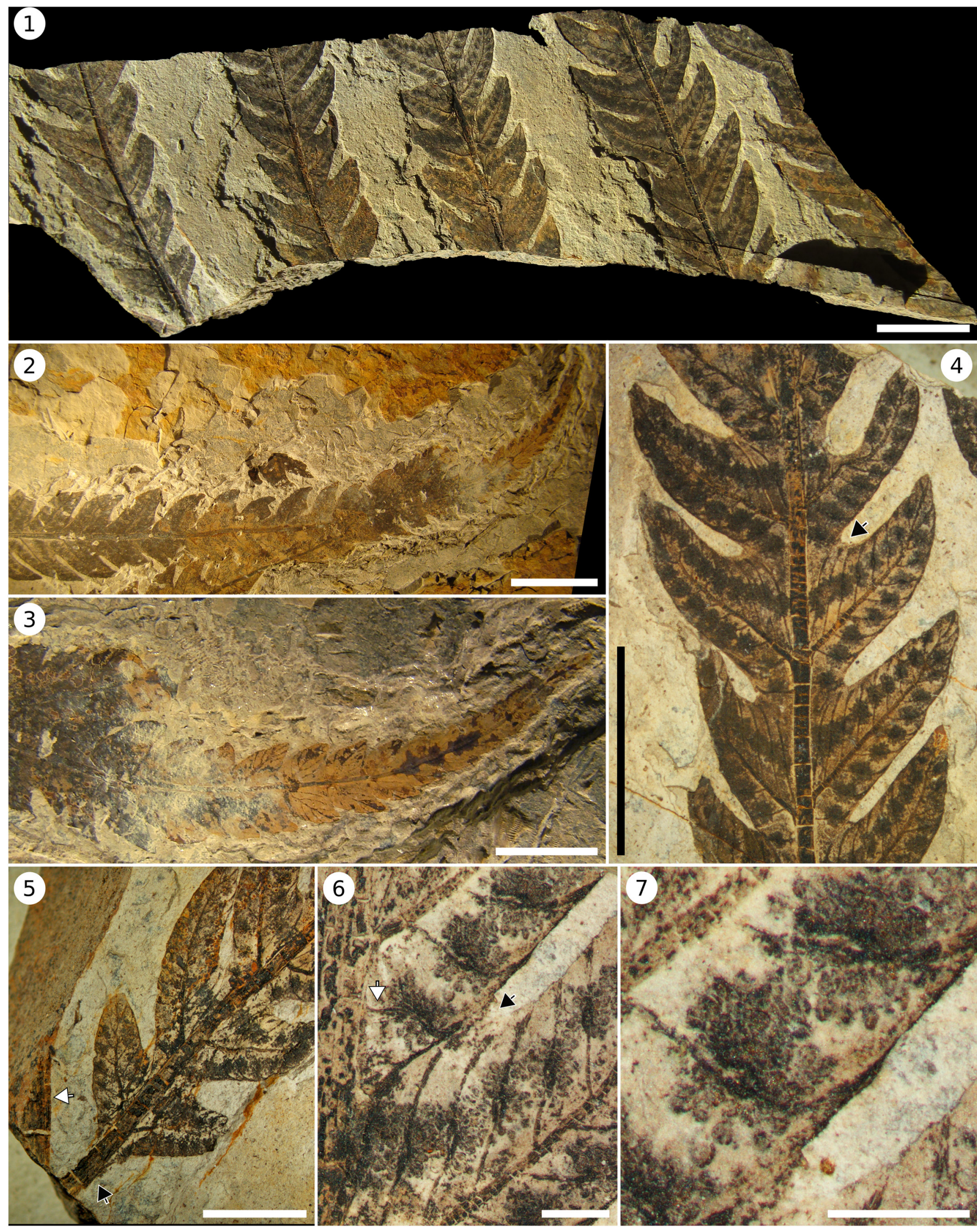

Plate I. Tapelrayen helgae gen. et sp. nov. 1. General aspect of the holotype (MAPBAR 2999-3). 2. Pinna (MAPBAR 6700-3). 3. Distal part of pinna (MAPBAR 6700-3). 4. Detail of 1 showing the middle part of a pinna.Arrow points to sinus membrane (MAPBAR 2999-3). 5. Left side pinna of 1 enlarged, showing basal part with a petiolule (black arrow) attached to a rachis fragment (white arrow) (MAPBAR 2999-3). 6. Basal part of segments and sinus showing veinlet diverging from costa (white arrow) and sinus membrane (black arrow) (MAPBAR 2999-3e). 7. Sori showing indusia and sporangia (MAPBAR 2999-3). Scale bar 1-2, $4=1 \mathrm{~cm} ; 3,5=0,5 \mathrm{~cm} ; 6-7=0,1 \mathrm{~cm}$. 

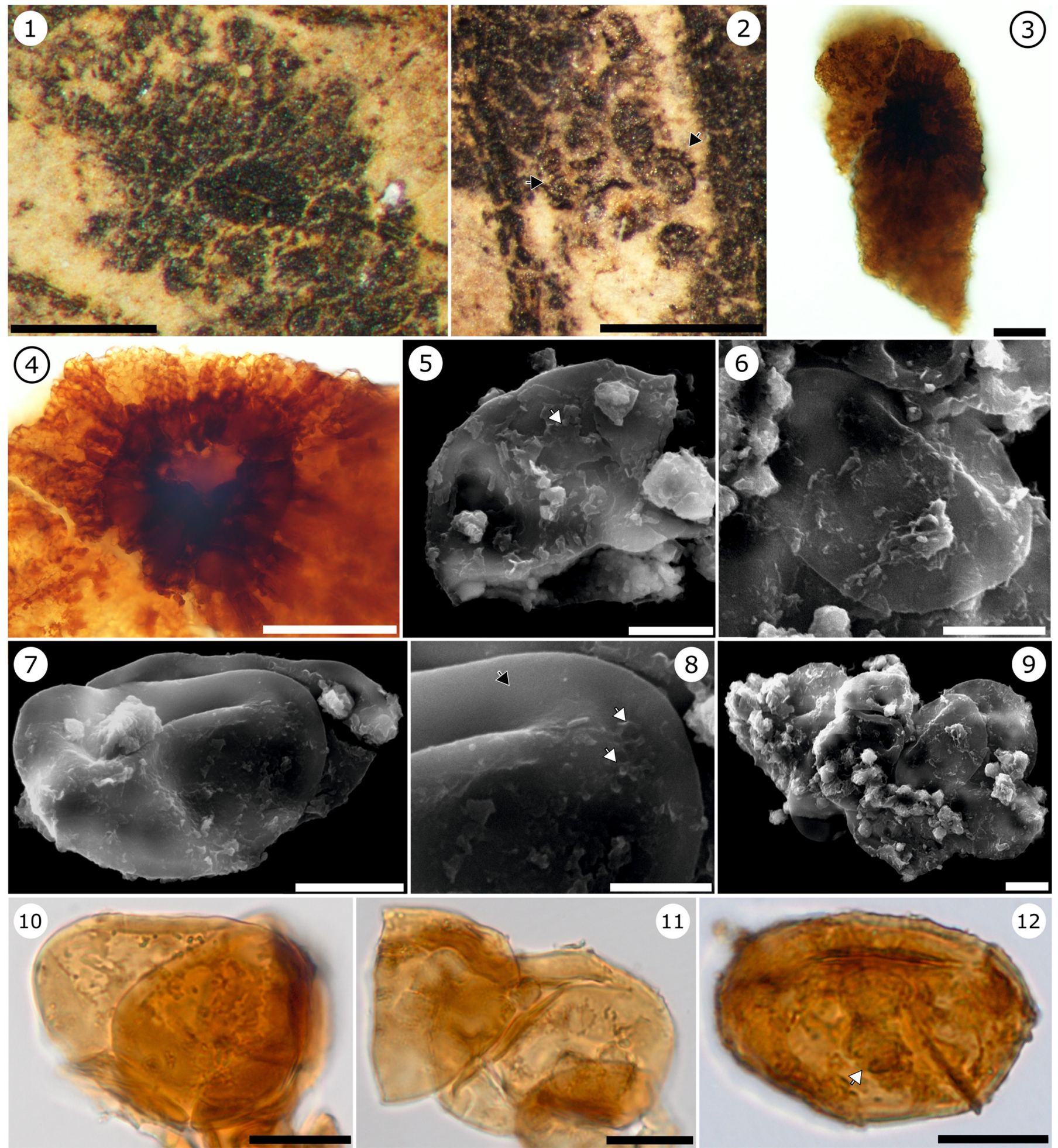

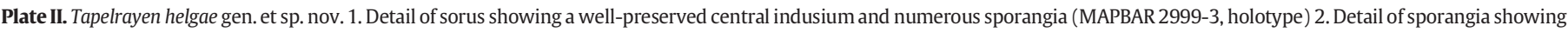

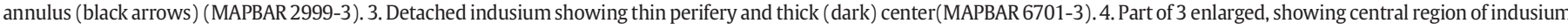

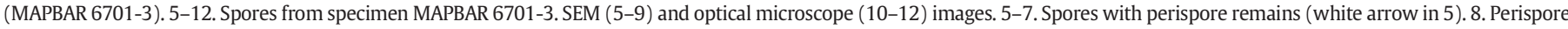

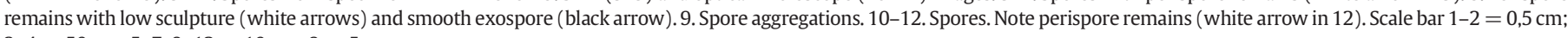
$3-4=50 \mu \mathrm{m} ; 5-7,9-12=10 \mu \mathrm{m} ; 8=5 \mu \mathrm{m}$.

(1987). In this sense, Tapelrayen helgae has a Type 2 pinnae (i.e. basal segments reduced) and Type 2 veins (basalmost lateral veins free or connivent, reaching the margin below the sinus, or not reaching it, ending below the sinus, Fig. 2) (Ponce, 1987). This combination of characters is recognized in Thelypteridaceae species referred to Christella, in particular the neotropical species Christella grandis with its several varieties (Ponce, 1987, 2007, 2016). However, Tapelrayen helgae differs from this species by having fewer lateral veins, a reduction of the first pair of segments of the pinnae (and not the following pairs as in the extant species), and the presence of the first basiscopic veinlet that 
diverges from the costa. The latter character is also absent in other species of Christella, such as Ch. conspersa, Ch. dentata, Ch. hispidula, Ch. patens and Christella berroi. Ponce (2016) states that Christella berroi and Thelypteris (Cyclosoriopsis) browniana (probably a species of Christella, see Supplementary Material 1 for all authorships) are closely related to Christella grandis, but these latter species can be separated from it by having enlarged basal segments of the pinnae (Ponce, 2016), a character also absent in the fossil taxon. Unfortunately, recent phylogenetic analyses of Thelypteridaceae (Almeida et al., 2016; He and Zhang, 2012) had a poor sampling of southern South American species as those above mentioned to evaluate if they are basal or derived members of the Christelloid clade. Steiropteris (sensu PPG I) includes representatives that share features with Tapelrayen helgae, as for example Steiropteris lonchodes (D.C. Eaton) Pic. Serm. This species has falcate segments, sinus membrane, sorus on the lateral veins, and a basal lateral vein diverging directly from the costa; but unlike Tapelrayen helgae it develops a pseudo-vein (keel) from the sinus to the costa. In addition to $S$. lonchodes, other American species of Steiropteris are comparable toTapelrayen helgae. Among them stand out Steiropteris deltoidea (Sw.) Pic. Serm. and S. buchtienii (A.R. Sm.) Salino et T.E. Almeida by having a similar venation pattern. Furthermore, S. buchtienii shares with Tapelrayen helgae the depth of pinnae incision, rate of segment reduction toward pinnae apex and pinnae spacing. However, both extant species differ from Tapelrayen helgae by developing of a pseudo-vein (keel) from the sinus to the costa, as well as in other character states. Steiropteris fendleri (D. C. Eaton) Pic. Serm. also resembles Tapelrayen helgae in the presence of a veinlet diverging from the costa but differs by having an excurrent vein formed from the fusion of more than one pair of lateral veins and the absence of a petiolule.

Tapelrayen helgae can also be compared in gross morphology with members of the Dryopteridaceae, namely of the genus Ctenitis. Among them Ctenitis nervata (Fée) R.S. Viveros et Salino is the most similar to the fossil species, with a comparable venation pattern, presence of a moon-shaped sinus membrane and a petiolule at the base of the pinna. The genus Ctenitis has a distinctive type of multicellular hairs, called catenate hairs (Kramer et al., 1990; Ponce and Arana, 2016). Their presence is the main criteria applied to identify the genus. The absence of these hairs in the fossils could reflect the morphology of the plants or be a taphonomic bias and as such an affinity with Ctenitis cannot be discarded.

Fertile traits recognized in T. helgae (e.g. position and shape of sori, reduced indusia, vertical annulus, monolete spore) fit with Thelypteridaceae and Dryopteridaceae features. Spores with a smooth exospore is another feature found in both families (Tryon and Lugardon, 1991) and therefore not useful to narrow affinity of the fossil. As a result we refer the new taxon to the most inclusive clade containing both families.

Remarks: Pinna costae in Tapelrayen helage (as observed in the Holotype MAPBAR 2999-3) appear grooved, a feature that can only be observed when carbon residues are removed. Considering this, even though the leaves are preserved with their abaxial side upwards (judging from the presence of sori) the position of the groove is presumed to be adaxial.

Fossil form. Eupolypod incertae sedis

Fig. 3b. Plate III.

Thelypteridaceophyllum sp. 2 Machado, 2019. figs. 20,21.

Locality: Arroyo Chacay.

Studied material: MAPBAR 6711-3Stratigraphic Horizon: Huitrera Formation.

Age: Eocene.

Description: Complete leaves unknown. Fertile leaves unknown. Sterile leaf pinnate, at least $6,2 \mathrm{~cm}$ long, $5 \mathrm{~cm}$ wide (Plate III, 1 ), almost exclusively preserving segments on the acroscopic side of pinnae (Plate III, 1-3); rachis stout, straight, up to $3,5 \mathrm{~mm}$ wide, adaxially grooved (Plate III, 1-3); groove not decurrent to that of lower order; costa stout, straight, 0,5-1,1 mm wide, adaxially grooved (Plate III, 2-3, 5).
Pinnae linear and pinnatifid, $6,1 \mathrm{~cm}$ long, $1,4 \mathrm{~cm}$ wide, suboppositely attached to the rachis with a short petiolule of $1,2 \mathrm{~mm}$ long at $40-60^{\circ}$ angle that decreases distally (Plate III, 1-3). Segments elliptical with acute apex and entire margins, 6-7,8 $\mathrm{mm}$ long, 3,4-4 mm wide, size decreasing toward pinna apex, $1 / \mathrm{w}$ ratio $1,88: 1$, alternately attached to the costa forming a $45-60^{\circ}$ angle (Plate III, 2-5). Adjacent segments fused from the base by $2 / 5$ of their total length. Sinuses acute without sinus membrane (Plate III, 3-5). Segments vascularized by a midvein and approximately nine pairs of unbranched lateral veins notably arched acroscopically reaching the margin without anastomosis (Plate III, 3-5). Midvein $0,1-0,2 \mathrm{~mm}$ wide at its base, straight or sinuous, slightly flexuous in some segments. Lateral veins arising from midvein at $20-55^{\circ}$, alternate to opposite, with catadromous dissection. Basalmost pair of laterals from adjacent segments connivent at the sinus or fusing near the sinus developing a short excurrent vein (Type 2 or Type 3 venation pattern sensu Ponce, 1987; Plate III, 4-5).

Comparison with fossil species:

Eupolypod incertae sedis can be separated from Tapelrayen helgae by having morphologically different segments, and lacking a basiscopic vein emerging from the costa and the sinus membrane. The studied remains are similar in gross morphology to Goniopteris patagoniana (Berry, 1938), collected from the same unit at the Pichileufu locality. However, both species differ in the number of lateral vein pairs per segment, with G. patagoniana having four to five pairs and Eupolypod incertae sedis having nine pairs. Cyclosorus stiriacus, cited for the Cenozoic of Europe, differs from Eupolypod incertae sedis in having several veinlets that converge to a long excurrent vein (Collinson, 2001; Kvaček et al., 2011; Holý et al., 2012). Cyclosorus scutum from the Eocene of China, has one or more pairs of basal veinlets that converge forming an excurrent vein toward the sinus, and veinlets that are only slightly curved (Naugolnykh et al., 2016), whereas in Eupolypod incertae sedis lateral veins are more arched, often pointing toward the apex of the segments, and basal veinlets often converge below the sinus, not developing an excurrent vein (or, if developed, no other veinlet converges to it). Speirseopteris orbiculata, from the Paleocene of Canada, has proximal veinlets that meet the margin above the sinus, and sterile segments have veinlets that fork once, both features not observed in the studied fossil (Stockey et al., 2006). Thelypteridaceophyllum tertiarum, from the Miocene of India, has more elongate segments, inserted in a wider angle (Joshi and Mehrotra, 2003). Christella taxa from the Liuqu and Sanhaogou formations (China) have several lateral veins that connect between segments (Xu et al., 2019). The specimens reported by Berry (2019) as Cyclosorus s.l. have more elongate and bigger segments, bearing numerous lateral veins.

Comparisons with extant species and affinities:

Venation pattern observed in the fossil (goniopteroid venation pattern) is observed in taxa included in Eupolypods (Kramer et al., 1990; Smith, 1990). Eupolypod incertae sedis has Type 2 venation pattern (Ponce, 1987) and the only basalmost segment preserved seems to be of similar size of the rest of the segments (similar to Type 1 pinna sensu Ponce, 1987). Many Argentinian species included in Christella, Cyclosorus and Goniopteris share this venation pattern, but most seem to have different segments morphology and size, being the fossil taxon smaller (Ponce, 1987, 2016). However, given the fragmentary nature of the specimen, absence of entirely preserved margins and basiscopic segments, and fertile remains, comparisons are difficult and make it impossible to propose close relationships to any particular taxon. Furthermore, given the lack of diagnostic features the affinities with the Thelypteridaceae or Dryopteridaceae cannot be clarified. Due to these factors it is here preferred to left these remains in open nomenclature.

Suborder: ASPLENIINEAE H.Schneid. et C.J.Rothf.

Family: THELYPTERIDACEAE Ching ex Pic.Serm.

Genus: Cyclosorus Link sensu Almeida et al., (2016).

Type species: Cyclosorus interruptus (Willd.) H.Itô.

Fossil form: Cyclosorus sp. cf. C. interruptus.

Fig. 3c. Plate IV 

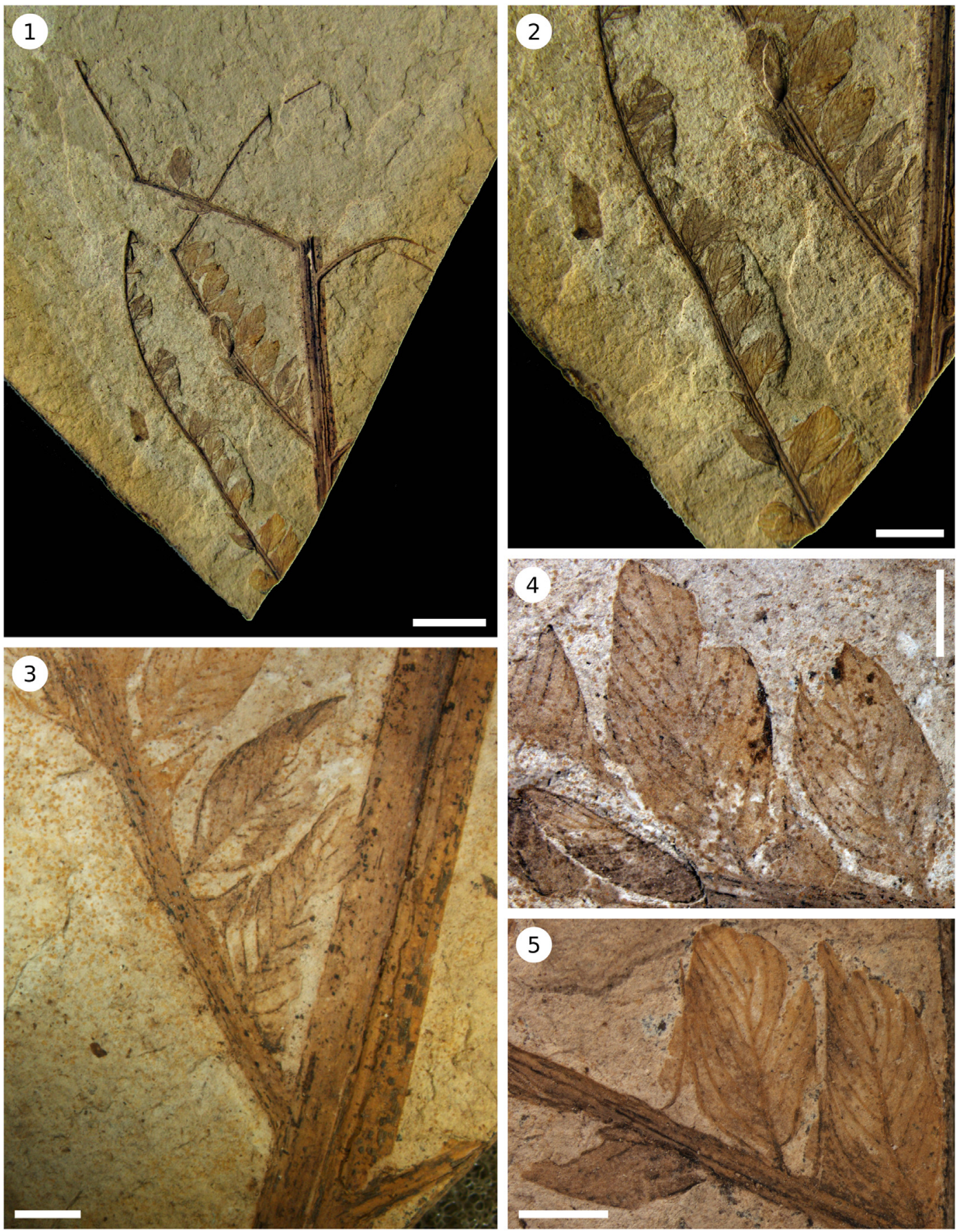

Plate III. Eupolypod incertae sedis (MAPBAR 6711-3). 1. General aspect. 2-3. Fig. 1 enlarged, showing pinna attached to rachis. 4-5. Segments attached to costa. Scale bar $1=1 \mathrm{~cm} ; 2=$ $5 \mathrm{~mm} ; 3-5=2 \mathrm{~mm}$.

Thelypteridaceophyllum sp. 1 Machado, 2019. figs. 18,19.

Locality: Arroyo Chacay.

Studied material: MAPBAR 6704-3, 7058-3.

Stratigraphic horizon: Huitrera Formation.

Age: Eocene.

Description: Complete Leaves unknown. Fertile leaf unknown. Sterile leaf pinnate, at least $5 \mathrm{~cm}$ long, 7,6 cm wide; rachis stout, straight, up to $1,4 \mathrm{~mm}$ wide, adaxially grooved (Plate IV, 2); costa stout, straight, up to $0,7 \mathrm{~mm}$ wide, adaxially grooved (Plate IV, $1-4$ ). Pinnae linear and pinnatifid, $3,8 \mathrm{~cm}$ long, $0,8-1 \mathrm{~cm}$ wide, attachedto rachis with a short petiolule at $40-60^{\circ}$, angle that decreases distally (Plate IV, 1-2).
Segments apparently ovate devoid of preserved apex, and with entire margins, 4-7 mmlong, 2-4,5 mm wide, size decreasing toward pinnae apex, $1 / \mathrm{w}$ ratio $1,6: 1$, attachedalternately to oppositely forming a $40-75^{\circ}$ angle decreasing distally (Plate IV, 1-4). Adjacent segments fused at base by $1 / 3-3 / 5$ of their total lengthforming acute sinuses without sinus membrane (Plate IV, 1-4). Segments vascularized by a midvein and 7-9 unbranched lateral veins that reach the margin without anastomosis (Plate IV, 1, 3-4). Midvein straight to slightly sinuous diverging from the costa at $40-75^{\circ}$. Lateral veins arising from midvein at $16-60^{\circ}$, alternate to opposite, with catadromous dissection. Basalmost pair of lateral veins from adjacent segments convergent 

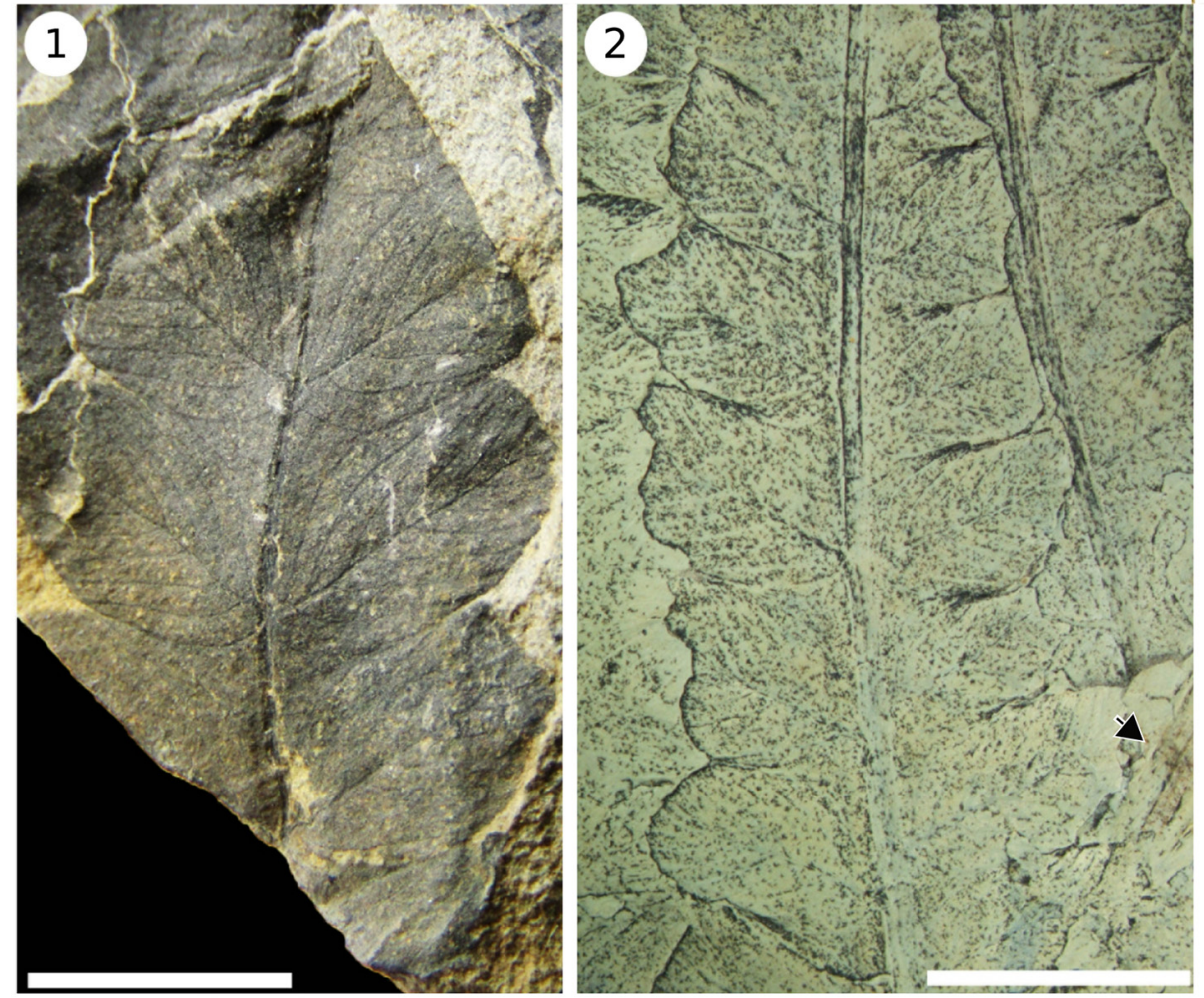
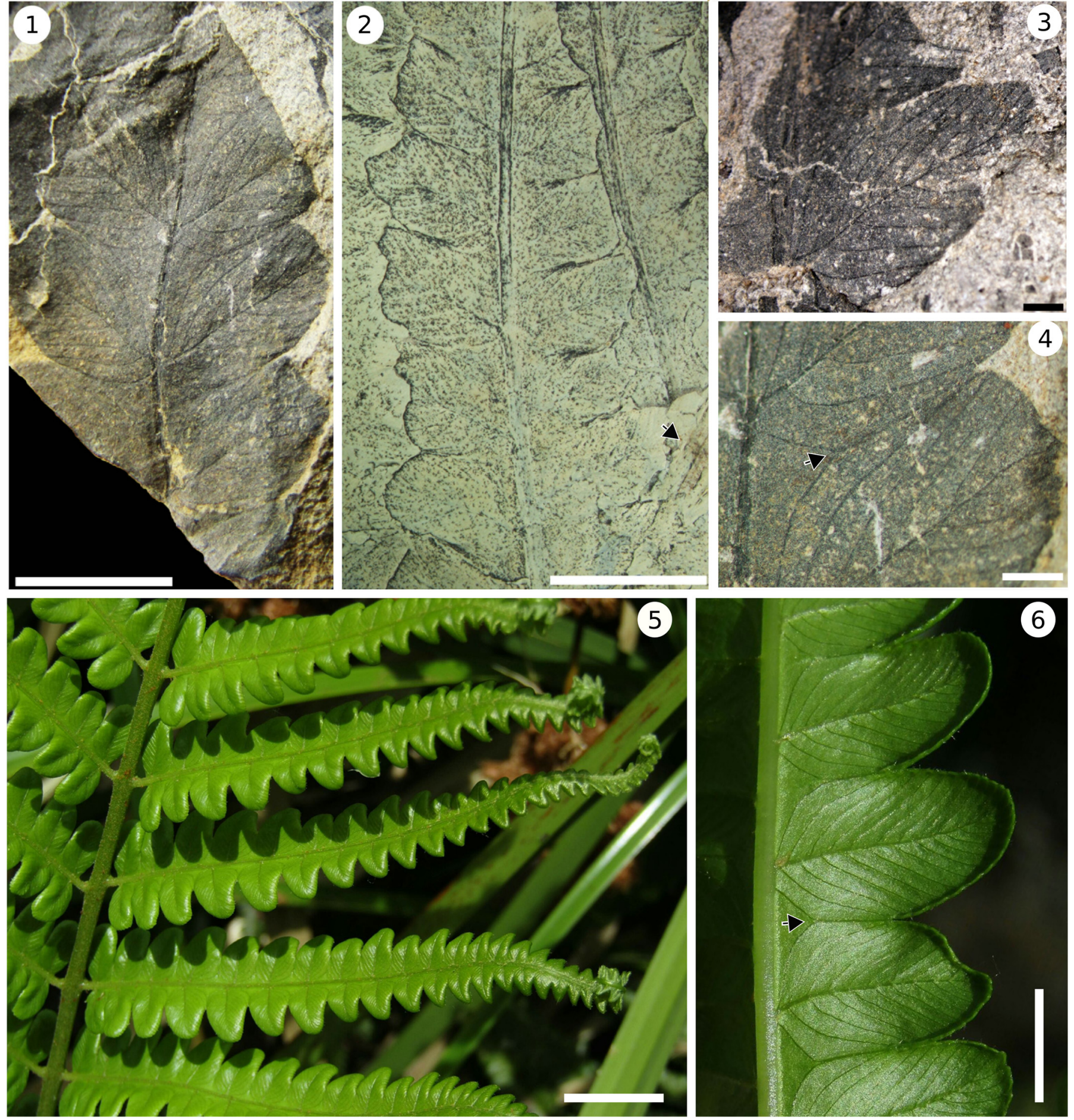

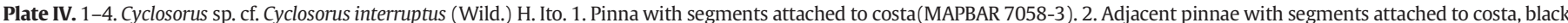

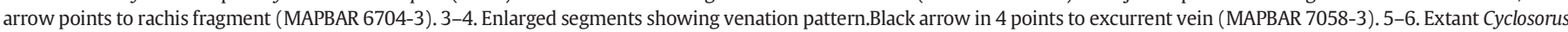

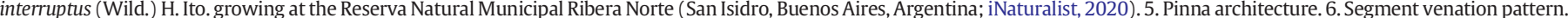
Black arrow points to excurrent vein. Scale bar $1-2,6=5 \mathrm{~mm} ; 3-4=1 \mathrm{~mm} ; 5=2 \mathrm{~cm}$.

below the sinus and fusing forming a triangular areole from which diverges a long excurrent vein that terminates at the sinus (Type 3 venation pattern sensu Ponce, 1987; Fig. 2, Plate IV, 4).

Comparisons with fossil species:

Cyclosorus sp. cf. C. interruptus can be distinguished from Tapelrayen helgae by having an excurrent vein that joins the sinus between adjacent segments, the ovate (non-falcate) shape and smaller size of the segments. Cyclosorus sp. cf. C. interruptus differs from Eupolypod incertae sedis in having long excurrent veins, and ovate (and not elliptical) shape of the segments, with a higher $\mathrm{l} / \mathrm{w}$ ratio.The studied remains are similar in gross morphology to Goniopteris patagoniana (Berry, 1938), collected from the same unit at the Pichileufu locality. However, several features preclude its referral to this species. In Cyclosorus sp. cf. C. interruptus, the lowermost lateral veins from adjacent segments 
converge forming a triangle, and from the point of convergence, an excurrent vein diverges, reaching the sinus. Contrarily, in Goniopteris patagoniana, no excurrent vein is developed (Berry, 1938). Furthermore, the number of lateral veins is higher in the specimens here studied. Cyclosorus stiriacus, differs from Cyclosorus interruptus and the studied fossils in having several lateral veins that converge to the excurrent vein (Collinson, 2001; Holý et al., 2012; Kvaček et al., 2011), whereas in the specimens here studied no lateral veins connect to the excurrent vein (apart from the basalmost ones that form the triangle from where the excurrent diverges). Cyclosorus scutum has lateral veins that are only slightly curved (Naugolnykh et al., 2016), whereas in Cyclosorus sp. cf. C. interruptus lateral veins are more arched, often pointing toward the apex of the segments, and also C. scutum can have more veins converging to the excurrent vein between its point of divergence and the sinus. Speirseopteris orbiculata has proximal veinlets that meet the margin above the sinus, and sterile segments have veinlets that fork once (Stockey et al., 2006) both features not observed in the studied fossil. Thelypteridaceophyllum tertiarum (Joshi and Mehrotra, 2003) has more elongate segments inserted in a wider angle. Specimens referred to Christella from the Liuqu and Sanhaogou formations (China) have several lateral veins that connect between segments (Xu et al., 2019). The materials reported as Cyclosorus s.l. by Berry (2019) have deeply lobed pinnae with bigger and more elongate and sometimes falcate segments. Fossils assigned to Thelypteris interrupta (Willd.) Iwatsuki (Cyclosorus interruptus sensu Almeida et al., 2016) have been reported from the Miocene Palo Pintado Formation, Salta Province, Argentina (Robledo et al., 2015) and are comparable to the material here described.

Comparison with extant species and affinities:

Cyclosorus sp. cf. C. interruptus has Type 3 venation pattern (i.e. basal pair of veins anastomosing forming an excurrent vein toward the sinus), feature present in Cyclosorus interruptus, but also in some species of Christella and Goniopteris (e.g. Christella conspersa, Ch.dentata, Ch. hispidula, Goniopteris riograndensis, G. tetragona and G. burkartii). Among these taxa, Cyclosorus interruptus, the only recognized species of the genus by Ponce $(1987,2016)$ and Almeida et al. (2016), is the most comparable with the studied fossil. Both taxa have long excurrent veins, arching veinlets, comparable size and morphology of segments, and number of veinlets in each segment (Ponce, 1987, 2016; Plate IV, 5-6). It is difficult to separate the fossil remains from the extant taxon in light of the preserved characters, but given its fragmentary nature and absence of fertile specimens, we prefer to avoid referring it to the extant species, leaving it in open nomenclature. The extant Cyclosorus interruptus is distributed in America, from Florida (USA) to Argentina and Chile (Ponce, 1987, 2016).

\section{Discussion}

5.1. Morphological traits and evolutionary divergence times of Thelypteridaceae and Dryopteridaceae

The venation pattern of the studied fossils is recognized among living representatives of the eupolypod clade (sensu PPG I, 2016), in the families Thelypteridaceae and Dryopteridaceae (Kramer et al., 1990; Smith, 1990; Ponce and Arana, 2016; Stockey et al., 2006). Some Dryopteridaceae (e.g. genus Ctenitis) and Thelypteridaceae share morphologic features of the leaves, such as ultimately pinnatifid leaf organization, sinuses between segments developing a membranaceous lamina (sinus membrane) or not, venation anastomosed of goniopteroid type or, if free with only basal pairs of lateral veins connected (developing an excurrent vein or not) or only connivent toward the sinus, basalmost lateral veins that can diverge directly from the costa instead of the midvein and sori borne on lateral veins (Kramer et al., 1990; Smith, 1990). These similarities explain the fact that the extant representatives of Thelypteridaceae were initially included in Dryopteridaceae (Christensen, 1907; Christensen, 1913), until their recognition as a separate family (Pichi Sermolli, 1970). Collinson (2001) states that Thelypteridaceae are characterized by petioles proximally having two hippocampiform vascular strands, which become fused distally developing a U-shaped stele, catadromy of the lamina and the presence of simple glandular hairs on the axes. However, the latter character may be absent in some Thelypteridaceae and also present in Dryopteridaceae (Kramer et al., 1990; Ramos Giacosa et al., 2017). On the other hand, Dryopteridaceae have two main vascular bundles on the base of the petiole, but also can have smaller ones, all of which become fused distally, but not into a U-shaped strand. Additionally, they can have hairs on the leaf or be glabrous. The spores of both Dryopteridaceae and Thelypteridaceae have variable perispore ornamentation, and the exospore can be from gemmulated to smooth in Thelypteridaceae and smooth or slightly undulate in Dryopteridaceae (Tryon and Lugardon, 1991; Moon and Sun, 2008). Some works have used the presence of an ornamented exospore to rule out affinities with the Dryopteridaceae (Stockey et al., 2006), but since its absence cannot be used to assert affinities (both families may have spores with smooth exospore) this character is only partially useful for familial recognition. Thus, the only characters that can be reliably used to differentiate the two families are those of the petiole vascular strands. In fossil specimens when no petiolar remains are preserved, or if petiole is preserved as impression/compression without anatomical details, it is not possible to accurately distinguish one family from the other. Divergence time estimates for both families are not useful to evaluate probable affinities for the Arroyo Chacay ferns either, since both clades (Thelypteridaceae and Dryopteridaceae) apparently diverged in the Cretaceous (Schneider et al., 2004; Regalado et al., 2017), being well established by Eocene times. Additionaly the divergence time estimate for the genus Ctenitis is early Paleocene (Hennequin et al., 2017) making it impossible to narrow down the options of probable affinities. Interestingly, the estimated divergence time between Oreopteris and the Cyclosoroid clade (sensu Almeida et al., 2016) is middle Eocene (Schuttpelz and Pryer 2009, node 203), which is encompassed in the age inferred for Arroyo Chacay fossil site. Nevertheless, that estimated divergence time corresponds to the age of putative cyclosoroid fossils used as calibration point (Schuettpelz and Pryer, 2009, fig. S1, Table S2). More studies of fossil material might shed new light on past diversification and migration of the Thelypteridaceae.

\subsection{Taxonomy and generic delimitation of the Thelypteridaceae: An unresolved issue}

Thelypteridaceae is one of the most abundant and diverse families of extant ferns, reaching circa 950 species (Smith et al., 2006; Almeida et al., 2016). Although most studies recognize this family as monophyletic, relationships between genera are far from solved. The number of genera identified in this clade ranges from 32 (Pichi Sermolli, 1977) to a single one (Morton, 1963), and current knowledge of the family based on molecular phylogenies reveals that none of the previously published generic delimitations is satisfactory (He and Zhang, 2012; Almeida et al., 2016). Furthermore, taxonomy of extant taxa is often based on the type of indument, presence of glands, features of the spores, and even karyology (Smith, 1990; He and Zhang, 2012; Almeida et al., 2016), characters infrequently preserved in most fossil impression-compressions. Many features observable in fossil leaf remains, such as venation pattern and type of indusia have high levels of homoplasy (Smith, 1990; He and Zhang, 2012). As a result, referral of fossil remains to extant genera of the Thelypteridaceae is tentative.

Recent studies on the family recover well defined clades (not necessarily equivalent to currently recognized genera), and some of these possess apparent morphological synapomorphies (He and Zhang, 2012). Using a molecular database Almeida et al. (2016) recognize two major clades, the Phegopteroid and the Thelypteroid clade. Genera included in the Phegopteroid clade (i.e. Macrothelypteris, Pseudophegopteris and Phegopteris) have free veins usually forked and not reaching the 
margins of the segments, whereas veins reach the margins in the Thelypteroid clade (He and Zhang, 2012; Almeida et al., 2016).

Four major clades are recognized in the Thelypteroid clade, i.e. Thelypteris s.s., Amauropeltoid clade, Oreopteris and the Cyclosoroid clade (Almeida et al., 2016). Three genera are recognized in the Amauropeltoid clade, i.e. Amauropelta, Metathelypteris and Coryphopteris (Almeida et al., 2016). Eight monophyletic genera (Steiropteris, Cyclogramma, Stegnogramma, Goniopteris, Cyclosorus, Mesophlebion, Ampelopteris and Meniscium, the latter four grouped in the Meniscioid clade) and a clade of ambiguous taxonomy (Christelloid clade) are recognized in the Cyclosoroid clade (Almeida et al., 2016). Among the Christelloid clade, generic delimitations are less clear with species historically referred to many genera, i.e. Christella, Sphaerostephanos, Pneumatopteris, Amphineuron, Chingia, Plesioneuron, Pronephrium, Abacopteris, Pseudocyclosorus, Trigonospora and Glaphyropteridopsis (Almeida et al., 2016). For the time being, it results difficult to segregate among these taxa using molecular data and some of them (e.g. Christella and Pronephrium) are either polyphyletic or paraphyletic (PPG I, 2016). In summary, latest work PPG I (2016) recognizes monophyletic genera such as Phegopteris, Amauropelta, Cyclosorus, Goniopteris, Steiropteris, etc., but also polyphyletic or paraphyletic ones like Christella and Pronephrium. Considering all this, the study of thelypteridacean fossils is hindered by the delimitation of modern genera using molecular characters or morphological ones of difficult (or even impossible) preservation in fossils (especially impression/compression fossil) and by the fact that the delimitation itself remains partially unresolved.

\subsection{Criteria previously followed to classify dryopteroid/thelypteroid fossil ferns}

When reviewing the Cenozoic record of ferns, Collinson (2001) stated that many fossils have been assigned to different families without conclusive evidence, and extensive revision is needed (Collinson, 2001). Good examples are the record of Dryopteridaceae and Thelypteridaceae. Collinson remarks that many former records of Dryopteris could represent Thelypteridaceae, and that revision of the record of both families is of great necessity. She also states that some fossils are of uncertain generic and familiar affinities. The impossibility of differentiating between some Dryopteridaceae and Thelypteridaceae with characters of the lamina alone renders much of the fossil record of these families of doubtful affinities (Collinson, 2001). Furthermore, she states that many species of fossil Thelypteridaceae were separated by characters that may be variable among species, including veins features (and this is apparently also the case for extant Thelypteridaceae as noted by Smith (1990). A complete revision of many fossil species referred to this family is probably needed, not only to evaluate segregation between species but also their generic and even familiar placement. Many fossils with free or goniopteroid venation pattern, pinnatifid organization, and catadromous segments and venation have been assigned to Thelypteridaceae in the past. When this is the case two alternatives are plausible. The first one is the assignment of fossils to extant genera of the family, without having unequivocal evidence of affinity with Thelypteridaceae (e.g., Cyclosorus, Goniopteris, Pronephrium). The other is the proposal of new fossil genera to encompass the fossil specimens (Thelypteridaceophyllum Joshi et Mehrotra, 2003; Speirseopteris Stockey et al., 2006). These practices have, in some cases, caused different problems which are listed below:

\subsubsection{Taxa with diagnosis that allow the inclusion of very different fossil leaves}

This is the case of Polypodites stiriacum (Unger), more frequently referred to as Pronephrium stiriacum (Unger) Knoblock et Kvaček 1976. The diagnosis of this species is wide enough to encompass not only representatives of the Thelypteridaceae and Dryopteridaceae, but also leptosporangiate ferns of many other families. Not only the original material described by Unger (1847) lacks most of the characters that could indicate affinities with the extant genus Pronephrium (which has been rendered as polyphyletic by Almeida et al., 2016 and PPG I, 2016), but also lacks the diagnostic characters of the family Thelypteridaceae (Smith, 1990; Collinson, 2001). Nevertheless, Knobloch and Kvaček (1976) made a formal combination inferring the affinities of the material described by Unger, and in the following years, and to present day, there have been many reports of $P$. stiriacum across Europe for the Paleogene (Collinson, 2001; Pirnea and Popa, 2018). The problem of considering these findings as reports of the same past biological entity is that inferences made upon that data most certainly will lead to artificial results (especially when biogeographic and paleoenvironmental inferences are made). For example, Pirnea et Popa (2018) assign two fossils from the Oligocene and Miocene of Romania to P. stiriacum. The two fossils exhibit morphological differences but nonetheless can be included in the taxon due to its original diagnosis. Therefore, the authors attribute the differences observed between the fossils to ecological adaptations (Pirnea and Popa, 2018).

\subsubsection{Taxa with vague definitions}

The best example is Thelypteridaceophyllum Joshi et Mehrotra, the diagnosis of which is "A fossil fern frond assignable to the family Thelypteridaceae" (Joshi and Mehrotra, 2003). The authors do not discuss which traits are relevant to recognize a representative of this family (and, as was discussed above, it is almost impossible in impression/ compression fossils). Furthermore, the type specimen of Thelypteridaceophyllum tertiarum Joshi et Mehrotra 2003, type species of the genus, is a small fragment of a sterile leaf, which may be comparable with Thelypteridaceae, but also with Dryopteridaceae. Judging from the published images (Joshi et Mehrotra, 2003) and photographs of similar specimens from the same sediments (kindly provided by R.C. Mehrotra), it results difficult (impossible?) to conclusively assign these fossils to the Thelypteridaceae. In addition to the scarcely informative generic diagnosis, photographs of the type species lack enough detail to evaluate an emendation of the genus.

In summary, it results very difficult (or almost impossible) to classify certain fossil leaves as Thelypteridaceae or Dryopteridaceae, and it is not very rigorous to make inferences based on doubtful assignments. Considering the abovementioned (Sections 5.1, 5.2 and this section), we propose a new genera and species in the Eupolypod clade for three specimens, thus minimizing inferences about its interrelationships, as well as with extant genera. Other specimen is assigned to the Eupolypod clade and left in open nomenclature due to its fragmentary preservation. Finally, we compare the remaining specimens to the living species Cyclosorus interruptus because they share all preserved character states. However, given their fragmentary nature, it is left in open nomenclature until new specimens are found. If the affinity of the latter with the extant species were confirmed, it would extend the stratigraphic range to the Eocene suggesting probable evolutionary stasis for this taxon.

\section{Conclusions}

Three ferns comparable with Thelypteridaceae and Dryopteridaceae are described from the Huitrera Formation at Arroyo Chacay locality, increasing the number of fossil plant taxa for this Eocene unit of northern Patagonia, and expanding the knowledge of the scarcely known fern content of these Cenozoic assemblages of western Gondwana.

A new genus and species (Tapelrayen helgae gen. et sp. nov.) is defined to encompass portions of leaves preserving sori, characterized by having falcate segments, unbranched lateral veins, basalmost basiscopic veins arising from the costa, basalmost pair of adjacent laterals connivent toward the sinus, and bearing circular sori with c. 30 sporangia containing monolete spores with smooth exospore.

Another specimen is left in open nomenclature (Eupolypod incertae sedis), given the fragmentary nature and lack of diagnostic features. 
The remaining specimens are compared to the extant species Cyclosorus interruptus, a taxon already recorded in Neogene deposits of Argentina, by sharing all recognizable features. However, given their fragmentary nature, they are classified as Cyclosorus sp. cf. C. interruptus.

In most of the cases it results difficult (if not impossible) to have complete certainty on the affinities of ferns with goniopteroid venation, and many fossils assigned to Dryopteridaceae or Thelypteridaceae should be revisited in light on this fact, and also recent classification schemes for these families.

\section{Declaration of Competing Interest}

The authors declare that they have no known competing financial interests or personal relationships that could have appeared to influence the work reported in this paper.

\section{Acknowledgments}

Thanks are due to Helga Smekal, collector of many of the specimens here studied, and also to the Asociación Paleontológica Bariloche. We thank to the Ministerio de Turismo, Cultura y Deporte, Río Negro Province for providing the paleontological permission (Res. 941/2015). Agustín G. Martinelli, Laura Chornogubsky Clerici and Martín Ezcurra are thanked for allowing the use of the pneumatic hammer in the Paleontología de Vertebrados laboratory (MACN). Special thanks to Valeria Perez Loinaze (MACN) for helping with the study of in situ spores of Tapelrayen helgae.Thanks are extended to Peter Wilf (Department of Geosciences, Pennsylvania State University, USA) and R.C. Mehrotra (Birbal Sahni Institute of Palaeobotany, India) for providing photographs of fossil ferns used for comparative purposes. We also thank both anonymous reviewers and Editor Alejandra Gandolfo for their detailed comments which greatly improved the final version of the manuscript. This work was supported by ANPCyT-PICT 02356 and PI-UNRN 40-B-743.

\section{Appendix A. Supplementary data}

Supplementary data to this article can be found online at https://doi. org/10.1016/j.revpalbo.2021.104381.

\section{References}

Almeida, T.E., Hennequin, S., Schneider, H., Smith, A.R., Batista, J.A.N., Ramalho, A.J., Proite, K., Salino, A., 2016. Towards a phylogenetic generic classification of Thelypteridaceae: Additional sampling suggests alterations of neotropical taxa and further study of paleotropical genera. Mol. Phylogenet. Evol. 94, 688-700. https://doi.org/10.1016/j. ympev.2015.09.009.

Ardolino, A., Franchi, M., Remesal, M. y, Salani, F., 1999. El volcanismo en la Patagonia extraandina. In: Caminos, R. (Ed.), Geología Argentina. Subsecretaría de Minería de la Nación, Servicio Geológico Minero Argentino. Instituto de Geología y Recursos Minerales, Buenos Aires, pp. 579-612 Anales 29.

Barthel, M., 1976. Farne und Cycadeen: Eozäne floren des Geisetales. Abh. Zent. Geol. Inst. 26, 1-507.

Bechis, F., Encinas, A., Concheyro, A., Litvak, V., Aguirre-Urreta, B., Ramos, V., 2014. New age constraints for the Cenozoic marine transgressions of north-western Patagonia, Argentina $\left(41^{\circ}-43^{\circ} \mathrm{S}\right)$ : Paleogeographic and tectonic implications. J. S. Am. Earth Sci. 52, 72-93.

Berry, E.W., 1938. Tertiary flora from the Río Pichileufú, Argentina. Geol. Soc. Amer. Spec. Pap. 12, 1-149.

Berry, K., 2019. Cyclosorus (Thelypteridaceae) s. l. from K-Pg boundary strata in Central Colorado, USA: the oldest Thelypteridaceous (Cyclosoroid) fern fossils and their affinity to modern and fossil forms. Neues Jahrbuch für Geologie und Paläontologie Abhandlungen 293, 307-323.

Bomfleur, B., Escapa, I., 2019. A silicified Todea trunk (Osmundaceae) from the Eocene of Patagonia. PalZ, 1-6 https://doi.org/10.1007/s12542-019-00479-6.

Carvalho, M.R., Wilf, P., Hermsen, E.J., Gandolfo, M.A., Cúneo, N.R., Johnson, K.R., 2013. First record of Todea (Osmundaceae) in South America, from the early Eocene paleorainforests of Laguna del Hunco (Patagonia, Argentina). Am. J. Bot. 100, 1831-1848. https://doi.org/10.3732/ajb.1200637.

Cazau, L., Cortiñas, J., Reinante, S., Asensio, M., Bechis, F., Apreda, D., 2005. Cuenca de Ñirihuau. In: Chebli, G.A., Cortiñas, J., Spalletti, L.A., Legarreta, L., Vallejo, E.L. (Eds.),
Frontera Exploratoria de la Argentina, $6^{\circ}$ Congreso de Exploración y Desarrollo de Hidrocarburos, Mar del Plata, Argentina, pp. 251-273.

Ching, R.C., 1963. A reclassification of the family Thelypteridaceae from the mainland of Asia. Acta Phytotaxon. Sin. 8, 289-335.

Christensen, C., 1907. Revision of the American Species of Dryopteris of the Group of D. opposita. Kongel. Danske Vidensk.-Selsk. Skr. 7, Naturvidensk. Math. Afd. 4, 249-336.

Christensen, C., 1913. Monograph of the genus Dryopteris. Part I. The Tropical American Pinnatified-bipinnatifid species. Danske Vidensk. Selsk.Skrift.7, Naturvidensk. Math. Afd. 10, 55-282.

Coira, B., 1979. Episodios volcánicos cenozoicos en el área de Chajarahuaico Casabindo, Puna Jujeña. $7^{\circ}$ Congreso Geológico Argentino. Neuquén. Actas 2, 537-552.

Collinson, M.E., 2001. Cainozoic ferns and their distribution. Brittonia 53, 173-235. https://doi.org/10.1007/BF02812700.

Escosteguy, L., Geuna, S., Franchi, M., González Díaz, E., DalMolín, C., Cegarra, M., Wilson, C., Etcheverría, M., González, R., 2013. Hoja Geológica 4172-II, San Martín de los Andes. Provincias del Neuquén y de Río Negro. Instituto de Geología y Recursos Minerales, Servicio Geológico Minero Argentino. Boletín 409, 92 pp., Buenos Aires.

Falco, J.I., Litvak, V.D., Bechis, F., 2019. Evidencias de sedimentación y volcanismo contemporáneo en la Formación Huitrera (Eoceno), Arroyo Chacay, provincia de Río Negro. $12^{\circ}$ Congreso de Petrología Ignea, Córdoba. Actas Digitales.

Feruglio, E., 1941. Nota preliminar sobre la Hoja 40B, San Carlos de Bariloche. Boletín de Informaciones Petroleras 18, 27-64.

González Bonorino, F., González Bonorino, G., 1978. Geología de la región de San Carlos de Bariloche: Un estudio de las Formaciones Terciarias del Grupo Nahuel Huapi. Revista de la Asociación Geológica Argentina 33, 175-210.

Groeber, P., 1929. Líneas fundamentales de la geología del Neuquén, sur de Mendoza y regiones adyacentes. Dirección General de Minas, Geología e Hidrología. Boletín 58, 109 pp., Buenos Aires.

Groeber, P., 1954. La Serie Andesítica Patagónica, susrelaciones, posición y edad. Revista de la Asociación Geológica Argentina 9, 39-42.

He, L.J., Zhang, X.C., 2012. Exploring generic delimitation within the fern family Thelypteridaceae. Mol. Phylogenet. Evol. 65, 757-764. https://doi.org/10.1016/j. ympev.2012.07.021.

Hennequin, S., Rouhan, G., Salino, A., Duan, Y.F., Lepeigneux, M.C., Guillou, M., Ansell, S., Almeida, T.E., Zhang, L.B., Schneider, H., 2017. Global phylogeny and biogeography of the fern genus Ctenitis (Dryopteridaceae), with a focus on the Indian Ocean region. Mol. Phylogenet. Evol. 112, 277-289.

Holttum, R.E., Sen, U., Mittra, D., 1970. Studies in the family Thelypteridaceae 2.A comparative study of the type-species of Thelpypteris Schmidel, Cyclosorus Link, and Ampelopteris Kunze. Blumea 18, 195-215.

Holý, F., Kvaček, Z., Teodoridis, V., 2012. A review of the early Miocene mastixioid flora of the Kristina Mine at Hrádek nad Nisou in North Bohemia (The Czech Republic). Acta Musei Nationalis Pragae, Ser. B Hist. Nat. 68, 53-118.

iNaturalist.org, 2020. iNaturalist Research-grade Observations. Occurrence dataset https://doi.org/10.15468/ab3s5x accessed via GBIF.org on 2020-01-27. https:// www.gbif.org/occurrence/2460049514.

Joshi, A., Mehrotra, R.C., 2003. A thelypteridaceous fossil fern from the Lower Siwalik of the East Kameng District, Arunachal Pradesh, India. J. Geol. Soc. India 61, 483-486.

Knobloch, E., Kvaček, Z., 1976. Miozane Blatter floren vom Westrand der Bohemischen Masse. Rozpr. Ustred. Ustavu. Geol. 42, 1-130.

Kramer, K.U., Holttum, R.E., Moran, R.C., Smith, A.R., 1990. Dryopteridaceae. In: Kramer K.U., Green, P.S. (Eds.), Families and Genera of Vascular Plants Vol. 2, Pteridophytes and Gymnosperms. Springer-Verlag Berlin Heidelberg, Berlin, pp. 101-144.

Kvaček, Z., Teodoridis, V., Roiron, P., 2011. A forgotten Miocene mastixioid flora of Arjuzanx (Landes, SW France). Palaeontogr. Abt. B Palaophytol. 285, 3-111. https:// doi.org/10.1127/palb/285/2011/3.

Lellinger, D.B., 2002. A modern multilingual glossary for taxonomic Pteridology. Pteridologia 2A. v. 3. American Fern Society, Washington.

Machado, M.A., 2019. Estudio de helechos de la Formación Huitrera (Eoceno) procedentes de la localidad Arroyo Chacay, provincia de Río negro, Argentina. Tesis de Licenciatura en Paleontología, Facultad de Ciencias Exactas y Naturales, Universidad de Buenos Aires.

Mazzoni, M.M., Rapela, C.W., 1991. Características químicas e isotópicas de ignimbritas miocenas. Andes patagónicos septentrionales (SVZ), Argentina. $6^{\circ}$ Congreso Geológico Chileno, Viña del Mar. Actas. 1, pp. 125-128.

Melendi, D.L., Scafati, L.H., Volkheimer, W., 2003. Palynostratigraphy of the Paleogene Huitrera Formation in N-W Patagonia, Argentina. Neues Jahrbuchfür Geol. Paläontol. Abh. 228, 205-273.

Miller, I.M., Hickey, L.J., 2008. The Fossil Flora of the Winthrop Formation (Albian-Early Cretaceous) of Washington State, USA. Part I: Bryophyta and Pteridophytina. Bull. Peabody Mus. Nat. Hist. 49, 135-180. https://doi.org/10.3374/0079-032X-49.2.135.

Moon, S.M., Sun, B.-Y., 2008. Spore morphology of Korean Thelypteridaceae. Korean J. Plant Taxon. 38, 459-476 (in Korean). 10.11110/kjpt.2008.38.4.459.

Morton, C.V., 1963. The classification of Thelypteris. Am. Fern J. 53, 149-154.

Naugolnykh, S.V., Wang, L., Han, M., Jin, J.H., 2016. A new find of the fossil Cyclosorus from the Eocene of South China and its paleoclimatic implication. J. Plant Res. 129, 3-12. https://doi.org/10.1007/s10265-015-0765-0.

Noetinger, S., Pujana, R.R., Burrieza, A., Burrieza, H.P., 2017. Use of UV-curable acrylates gels as mounting media for palynological samples. Revista del Museo Argentino de Ciencias Naturales, Nueva serie 19, 19-23.

Pichi Sermolli, R.E.G., 1970. Thelypteridaceae. Fragmenta Pteridologiae II. Webbia 24, pp. 709-711.

Pichi Sermolli, R.E.G., 1977. Tentamen Pteridophytorum genera in taxonomicum ordinem redigendi. Webbia 31, 313-512. https://doi.org/10.1080/00837792.1977.10670077. 
Pirnea, R., Popa, M.E., 2018. Genus Pronephrium Presl 1851 (Thelypteridaceae) in Romania. J. Palaeogeogr. 7, 10. https://doi.org/10.1186/s42501-018-0012-4.

Ponce, M.M., 1987. Revisión de las Thelypteridaceae (Pteridophyta) Argentinas. Darwiniana 28, 317-390.

Ponce, M.M., 2007. Sinopsis de las Thelypteridaceae de Brasil central y Paraguay. Hoehnea 34, 283-333. https://doi.org/10.1590/S2236-89062007000300003.

Ponce, M.M., 2016. Thelypteridaceae. In: Zuloaga, F.O., Belgrano, M.J. (Eds.), Flora Vascular de La República Argentina Vol. 2, Licofitas, Helechos, Gymnospermae. Instituto de Botánica Darwinion, San Isidro, pp. 353-384.

Ponce, M.M., Arana, M.D., 2016. Dryopteridaceae: Bolbitis, Ctenitis, Cyclodium, Cyrtomium, Dryopteris, Lastreopsis, Parapolystichum, Rumohra. In: Zuloaga, F.O., Belgrano, M.J. (Eds.), Flora Vascular de La República Argentina Vol. 2, Licofitas, Helechos, Gymnospermae. Instituto de Botánica Darwinion, San Isidro, pp. 131-140.

PPG I, 2016. A community-derived classification for extant lycophytes and ferns. J. Syst. Evol. 54, 563-603. https://doi.org/10.1111/jse.12229.

Rabassa, J., 1974. Geología de la región de Pilcaniyeu-Comallo (Provincia de Río Negro, Argentina). Fundación Bariloche, Publicación 17, San Carlos de Bariloche.

Rabassa, J., 1978. Estratigrafía de la región de Pilcaniyeu-Comallo, provincia de Río Negro. Argentina. $7^{\circ}$ Congreso Geológico Argentino, Buenos Aires. Actas 1, pp. 731-746.

Ramos, V., 1982. Las ingresiones pacíficas del Terciario en el norte de la Patagonia (Argentina). $3^{\circ}$ Congreso Geológico Chileno, Concepción. Actas, pp. 263-288.

Ramos Giacosa, J.P., Gorrer, D.A., Giudice, G.E., Luna, M.L., 2017. Gametophyte development and conservation of Ctenitis submarginalis (Dryopteridaceae) in Buenos Aires Province, Argentina. Boletín de la Sociedad Argentina de Botánica 52 (4), 697-703.

Rapela, C.W., Spalletti, L.A., Merodio, J.C., 1983. Evolución magmática y geotectónica de la "Serie Andesítica" Andina (Paleoceno-Eoceno) en la Cordillera Norpatagónica. Revista de la Asociación Geológica Argentina 38, 469-484.

Rapela, C.W., Spalletti, L.A., Merodio, J.C., Aragón, E., 1984. El vulcanismo PaleocenoEoceno de la provincia volcánica Andino-Patagónica. 9 Congreso Geológico Argentino, Relatorio 1, pp. 189-213.

Rapela, C.W., Spalletti, L.A., Merodio, J.C., Aragón, E., 1988. Temporal evolution and spatial variation of early tertiary volcanism in the patagonian Andes $\left(40^{\circ} \mathrm{S}-42^{\circ} 30^{\prime} \mathrm{S}\right)$. J. S. Am. Earth Sci. 1, 75-88.

Regalado, L., Schmidt, A., Krings, M., Bechteler, J., Schneider, H., Heinrichs, J., 2017. Fossil evidence of eupolypod ferns in the mid-Cretaceous of Myanmar. Plant Syst. Evol. https://doi.org/10.1007/s00606-017-1439-2.

Robledo, M., Sarzetti, L., Anzótegui, L., 2015. Phytophagy on fossil ferns from Argentina (Palo Pintado Formation, Late Miocene): A review of their fossil record and ichnotaxonomy. Rev. Brasil. Paleontol. 18, 225-238. https://doi.org/10.4072/ rbp.2015.2.04.
Schneider, H., Schuettpelz, E., Pryer, K.M., Cranfill, R., Magallon, S., Lupia, R., 2004. Ferns diversified in the shade of angiosperms. Nature 428, 553-557. https://doi.org/ 10.1038/nature02361

Schuettpelz, E., Pryer, K., 2009. Evidence for a Cenozoic radiation of ferns in an angiosperm-dominated canopy. Proceedings of the National Academy of Sciences of the United States of America 106, 11200-11205. https://doi.org/10.1073/ pnas.0811136106.

Smith, A.R., 1990. Thelypteridaceae. In: Kramer, K.U., Green, P.S. (Eds.), Families and Genera of Vascular Plants Vol. 2, Pteridophytes and Gymnosperms. Springer-Verlag Berlin Heidelberg, Berlin, pp. 263-272.

Smith, A.R., Pryer, K.M., Schuettpelz, E., Korall, P., Schneider, H., Wolf, P.G., 2006. A classification for extant ferns. Taxon 55, 705-731. https://doi.org/10.2307/25065646.

Stockey, R.A., Lantz, T.C., Rothwell, G.W., 2006. Speirseopteris orbiculata gen. et sp. nov (Thelypteridaceae), a Derived Fossil Filicalean from the Paleocene of Western North America. Int. J. Plant Sci. 167, 729-736. https://doi.org/10.1086/501233.

Taylor, T., Taylor, E., Krings, M., 2009. The Biology and Evolution of Fossil Plants. Elsevier, Amsterdam https://doi.org/10.2307/1223352.

Tryon, R., 1960. A Glossary of Some Terms Relating to the Fern Leaf. Taxon, Vol. 9, No. 4 pp. 104-109.

Tryon, R., Lugardon, B., 1991. Spores of Pteridophyta. Springer-Verlag, New York https:// doi.org/10.1007/978-1-4613-8991-0.

Tryon, R.M., Tryon, A.F., 1982. Ferns and Allied Plants With Special Reference to Tropical America. Springer-Verlag, New York.

Unger, F., 1847. Chloris protogaea. Beiträge zur Flora der Vorwelt CX +150 pp., 50 pls.

Volkheimer, W., 1964. Estratigrafía de la zona extraandina del departamento de Cushamen (Chubut) entre los paralelos $42^{\circ}$ y $42^{\circ} 50^{\prime}$ y los meridianos $70^{\circ}$ y $71^{\circ}$. Revista de la Asociación Geológica Argentina 19, 85-107.

Wilf, P., Cúneo, N.R., Johnson, K., Hicks, J.F., Wing, S.L., Obradovich, J.D., 2003. High plant diversity in Eocene South America: Evidence from Patagonia. Science 300, 122-125.

Wilf, P., Johnson, K.R., Cúneo, N.R., Smith, M.E., Singer, B.S., Gandolfo, M.A., 2005. Eocene plant diversity at Laguna del Hunco and Río Pichileufú, Patagonia, Argentina. Am. Nat. 165, 634-650.

Wilf, P., Singer, B.S., Zamaloa, M.C., Johnson, K.R., Cúneo, N.R., 2010. Early Eocene 40Ar/ 39Ar Age for the Pampa de Jones plant, Frog, and Insect Biota (Huitrera Formation, Neuquén Province, Patagonia, Argentina). Ameghiniana 47, 207-216.

Xu, C.-L., Su, T., Huang, J., Huang, Y.-J., Li, S.-F., Zhao, Y.-S., Zhou, Z.-K., 2019. Occurrence of Christella (Thelypteridaceae) in Southwest China and its indications of the paleoenvironment of the Qinghai-Tibetan Plateau and adjacent areas. J. Syst. Evol. 57, 169-179. https://doi.org/10.1111/jse.12452. 
Eupolypod ferns with dryopteroid/thelypteroid traits from Arroyo Chacay (Huitrera Formation, Eocene), Río Negro Province, Argentina.

Matías A. Machado, Ezequiel I. Vera, Mauro G. Passalia, Mónica M. Ponce

Review of Palaeobotany and Palynology

Supplementary Material 1. Equivalences between Argentinean species of Thelypteridaceae named in Ponce (2016) and PPG I (2016).

\section{Species (sensu PPG I)}

Cyclosorus interruptus (Willd.) H. Itô

not formally combined

not formally combined

Christella conspersa (Schrad.) Á. Löve \& D. Löve

Christella dentata (Forssk.) Brownsey \& Jermy

Christella hispidula (Decne.) Holttum

Christella patens (Sw.) Holttum

not formally combined

Steiropteris lonchodes (D.C. Eaton) Pic. Serm

Steiropteris deltoidea (Sw.) Pic. Serm

Steiropteris buchtienii (A.R.Sm.) Salino et T.E. Almeida

Steiropteris fendleri (D.C. Eaton) Pic. Serm.

Goniopteris riograndensis (Lindm.) Ching

Goniopteris tetragona (Sw.) C. Presl

Goniopteris burkartii C. Chr. ex Abbiatti

\section{Genus (sensu PPG I) Ponce 2016 (subgenera given in parentheses)}

Cyclosorus

Christella

Christella

Christella

Christella

Christella

Christella

Christella

Steiropteris

Steiropteris

Steiropteris

Steiropteris

Goniopteris

Goniopteris

Goniopteris
Thelypteris (Cyclosorus) interrupta (Willd.) K. Iwats.

Thelypteris (Cyclosoriopsis) grandis A.R. Sm

Thelypteris (Cyclosoriopsis) browniana Ponce

Thelypteris (Cyclosoriopsis) conspersa (Schrad.) A. R. Sm.

Thelypteris (Cyclosoriopsis) dentata (Forssk.) E.P. St. John

Thelypteris (Cyclosoriopsis) hispidula (Decne.) C.F. Reed

Thelypteris (Cyclosoriopsis) patens (Sw.) Small

Thelypteris (Cyclosoriopsis) berroi (C. Chr.) C.F. Reed

$--$

Thelypteris (Goniopteris) riograndensis (Lindm.) C.F. Reed

Thelypteris (Goniopteris) tetragona (Sw.) Small

Thelypteris (Goniopteris) abbiattii C.F. Reed

Ponce, M.M., 2016. Thelypteridaceae, in: Zuloaga, F.O., Belgrano, M.J. (Eds.), Flora Vascular de La República Argentina. Vol. 2. Licofitas. Helechos. Gymnospermae. Instituto de Botánica Darwinion, San Isidro, pp. 353-384.

PPG I, 2016. A community-derived classification for extant lycophytes and ferns. J. Syst. Evol. 54, 563-603. doi:10.1111/jse.12229 